\title{
Bel ağrılı kişilerde lomber bölge benign, primer malign ve metastatik omurga tümörleri nasıl ayırt edilir, tanı ve tedavi yaklaşımı ne olmalıdır?
}

\author{
The differential diagnosis and the management of the spinal tumors \\ in patients with low back pain
}

\author{
Önder Ofluoğlu¹, Seyit Ali Gümüştaş² \\ ${ }^{1}$ Bahçeşehir Üniversitesi Tıp Fakültesi, Medical Park Göztepe Hastanesi, İstanbul \\ ${ }^{2}$ Yavuz Selim Kemik Hastalıkları Rehabilitasyon Hastanesi, Trabzon
}

\begin{abstract}
Bel ağrısına yol açan lomber bölge patolojilerinin sadece \%1'ini primer ya da metastatik tümörler oluşturmaktadır. Bu oran düşük görülmekle birlikte, gerek bel ağrısının toplumdaki sıklığının oldukça yüksek olması gerekse bel ağrısı etiyolojisinde yer alan en ciddi ve önemli nedenin malignite olması nedeniyle, birçok tümör olgusunun başlangıçta "nonspesifik bel ağrısı" tanısı ile sonuçlanacağı aşikârdır. Bu nedenle, bel ağrısı ile başvuran birçok hastada, klinik tablodan görüntüleme yöntemlerine kadar, ayırıcı tanıda hangi özelliklerin omurgada neoplastik süreçleri akla getirmesi gerektiğinin bilinmesi, hayati önem taşımaktadır. Çünkü, sorunun bir maligniteden kaynaklanma olasılığı gündeme geldiğinde, tanı aşamasından tedaviye kadar tüm yaklaşımın tümör yönetimi prensiplerine bağlı olarak devam etmesi gerekecektir. Bu aşamada doğru tanı ve tedavi yaklaşımlarının uygulanması, birçok hastada morbidite ve mortaliteyi önemli oranda azaltabilecektir. Bu derlemede, bel ağrısı ayırıcı tanısında sık görülen primer benign ve malign kemik tümörlerinin ve metastatik lezyonların tanısı ve yönetimi ana hatlarıyla aktarılmaktadır.
\end{abstract}

Anahtar sözcükler: bel ağrısı; tümör; ayırıcı tanı; tedavi
Primary or metastatic bone tumors constitute only $1 \%$ of lumbar pathologies in patient with low back pain. Although this rate can be regarded as very low, it is obvious that initially the most of the tumor cases will be diagnosed as nonspecific low back pain, since low back pain is quite common and aformentioned malignancy is the most serious cause of the pain. Therefore the knowledge of the clinical presentation and the differential diagnosis of the neoplastic lesions in lumbar vertebrae and management of the patients according to the oncologic principles is vital. Because, if it is likely that the problem is due to a malignancy, all the diagnostic approach and treatment principles will need to continue depending on tumor management. The implementation of proper diagnosis and treatment at this stage may reduce morbidity and mortality significantly. In this review, the diagnosis and the principles of management of the primary and metastatic lumbar tumors will be outlined.

Key words: low back pain; tumors; differential diagnosis; therapy
$\mathrm{B}$ el ağrısına yol açan lomber bölge patolojilerinin yaklaşık \%1'ini primer ya da metastatik tümörler oluşturmaktadır. Bu oran düşük görülmekle birlikte, gerek bel ağrısının toplumdaki sıklığının oldukça yüksek olması gerekse bel ağrısı etiyolojisinde yer alan en ciddi ve önemli nedenin malignite olması nedeniyle, birçok tümör olgusunun başlangıçta "nonspesifik bel ağrısı" tanısı ile sonuçlanacağı aşikârdır. Bu nedenle, bel ağrısı ile başvuran birçok hastada, klinik tablodan görüntüleme yöntemlerine kadar ayırıcı tanıda hangi özelliklerin omurgada neoplastik süreçleri akla getirmesi gerektiğinin bilinmesi, hayati önem taşımaktadır. Çünkü, sorunun bir maligniteden kaynaklanma olasılığı gündeme geldiğinde, tanı aşamasından tedaviye kadar tüm yaklaşımın tümör yönetimi prensiplerine bağlı olarak devam etmesi gerekecektir. Bu aşamada doğru tanı ve tedavi yaklaşımlarının uygulanması, birçok hastada morbidite ve mortaliteyi önemli oranda azaltabilecektir.

- İletişim adresi: Doç. Dr. Önder Ofluoğlu, Bahçeşehir Üniversitesi Tıp Fakültesi, Medical Park Göztepe Hastanesi Merdivenköy mahallesi, 23. Nisan Sokak, E5 üzeri No: 17, Göztepe, Kadıköy, İstanbul Tel: 0216 - 4684444 e-posta: oofluoglu@gmail.com

- Geliş tarihi: 17 Ağustos 2015 Kabul tarihi: 17 Ağustos 2015 

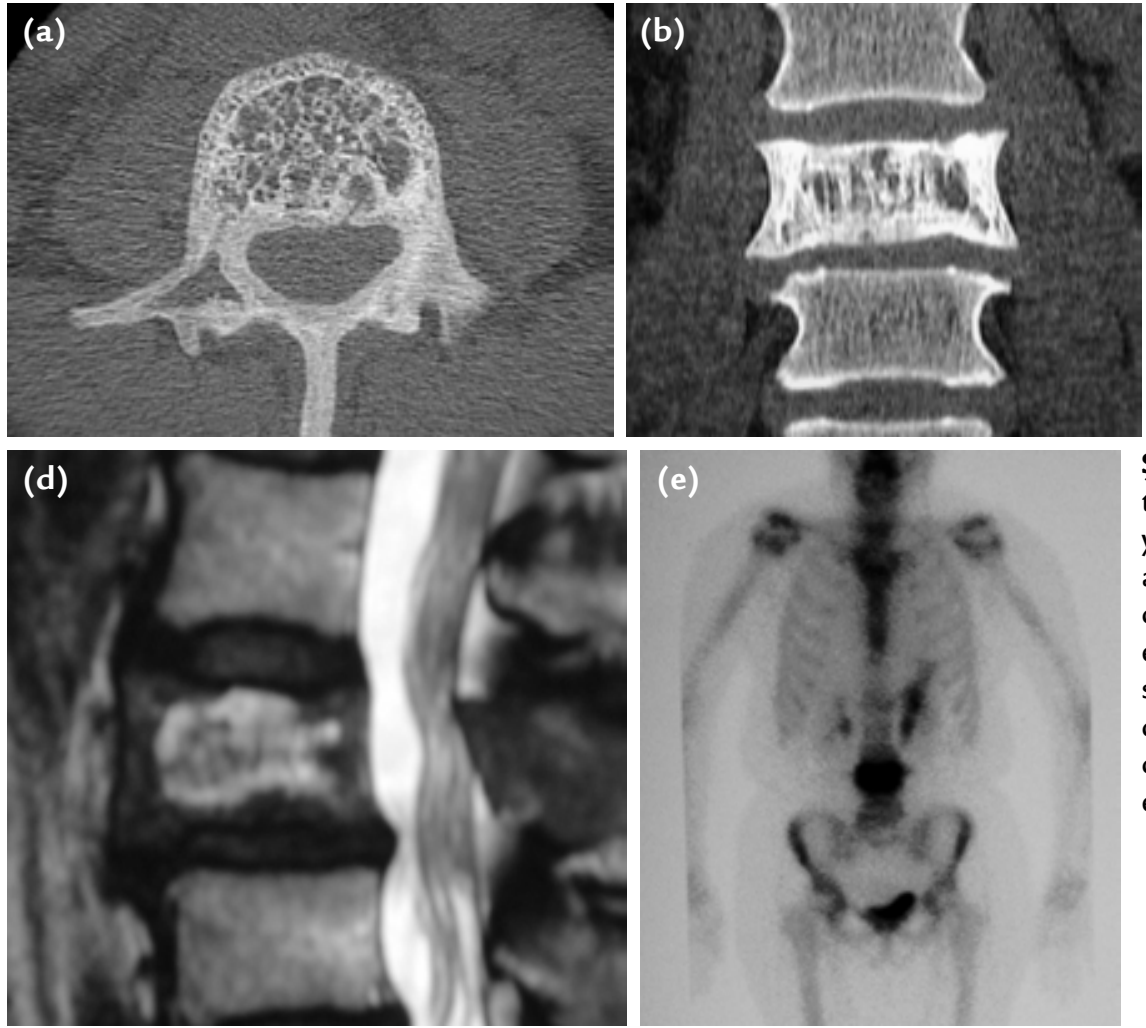

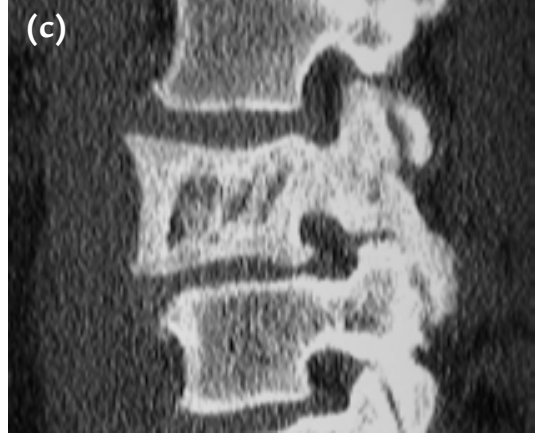

Şekil 1. Omurga tutulumu gösteren metabolik hastalıklar, tümör ayırıcı tanısında yer alması gereken durumlardandır. Bel ağrısı ile başvuran bu hastada; sintigrafide, L4 vertebrada yoğun aktivite artışına ek olarak serum alkalen fosfatazında yükselme, Paget hastalığı ve spinal neoplaziyi düşündürmüş; biyopsi, Paget hastalığını doğrularken, karsinom metastazı ekarte edilmiştir.
Omurga onkolojisinin, standart ortopedi ve omurga cerrahisi eğitimi içinde yeterli bir ağırlığa sahip olmaması nedeniyle, kaçınılmaz bir şekilde, birçok hastada önemli tanı ve tedavi hataları oluşabilmektedir. Bel ağrısı ile başvuran bir hastada ayırıcı tanı, algoritma ve klinik kılavuzlarının etkinliği konusunda görüş birliği bulunmamaktadır. Benzer şekilde, tümöre ait olabilecek bulgular da spesifik değildir. Bu nedenle, bir algoritma takibi yerine, temel kemik ve yumuşak doku klinik ve radyolojik yaklaşım prensiplerinin bilinmesi gereklidir.

\section{KLINIK DEĞERLENDIRME}

Omurga tümörü hastalarında ağrı, başlangıçta lokalize kemik destrüksiyonu ve periost iritasyonuna bağ|ı olarak ortaya çıkar, genellikle istirahate cevap vermez ve geceleri artış gösterir. Vertebra destrüksiyonu ileri derecede olan hastalarda, mekanik ağrı da görülebilir. Aksiyel iskelet ağrısına ek olarak, radiküler ağrı ya da miyelopati bulguları daha nadirdir. Benzer şekilde, oldukça nadir de olsa, metastatik hastalarda ya da hızlı büyüyen primer malign tümörlerde kauda ekina (cauda equina) sendromu görülebilir. Mesane ve barsak sfinkter disfonksiyonları, daha düşük bir hasta yüzdesinde, tanı ve tedavide ciddi gecikmesi olan hastalarda ortaya çıkabilmektedir. ${ }^{[1]}$
Klinik değerlendirme içerisinde "hastanın öyküsünde malignite" varlı̆̆ı, majör risk teşkil ederken, ileri yaş, açıklanamayan kilo kaybı ve istirahate rağmen ağrının geçmemesi, minör risk olarak görülmektedir. Bunun dışında, bazı tanı kılavuzlarında yer alan, hastanın çok genç $(<20)$ ya da 55 yaşından büyük olması, genel düşkünlük, nörolojik defisit ve mekanik olmayan bel ağrısı gibi semptomlar tümöre spesifik görülmemekte ve tanı değeri düşük bulunmaktadır. ${ }^{[2,3]}$

\section{LABORATUVAR}

Laboratuvar tetkikleri, kemik tümörleri tanısına genellikle katkıda bulunmaz. Bazı karsinomlarda olduğu gibi, tanı ve takiplerde kullanılabilecek bir kemik tümörü belirteci bulunmamaktadır. Bununla birlikte, hastalarda rutin kan tablosu ve biyokimyasal incelemelere ek olarak; sedimentasyon ve C-reaktif protein yüksekliği (özellikle lösemi, lenfoma ve Ewing sarkomu gibi yuvarlak hücreli tümörler), alkalen fosfatazda ve parathormonda artış (osteoblastik lezyonlar, metabolik lezyonlar ve metastazlarda), hiperkalsemi (yaygın metastatik hastalık), renal fonksiyon testlerinde bozulma, protein ve immün elektroforezde bozulma (multipl miyelom) olup olmadığı araştırılmalı$\operatorname{dır}\left(\right.$ Şekil 1). ${ }^{[4]}$ 

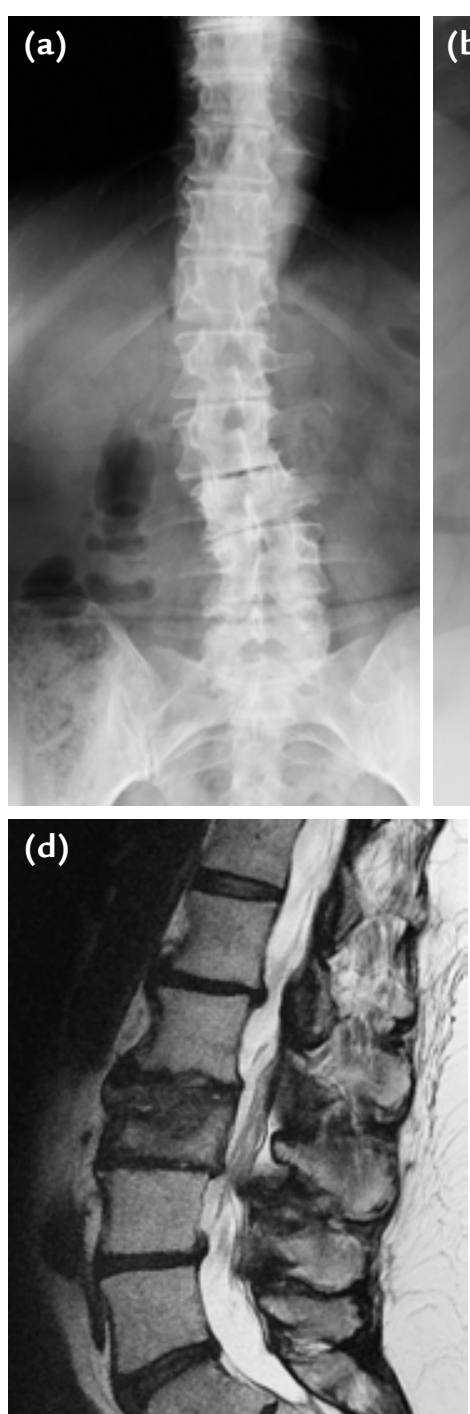
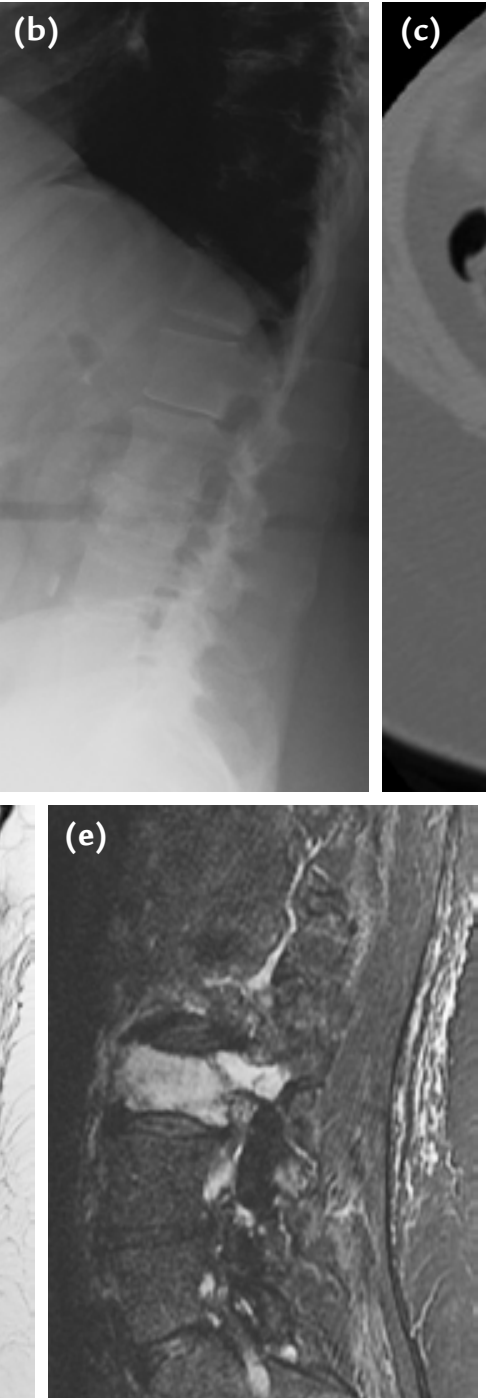

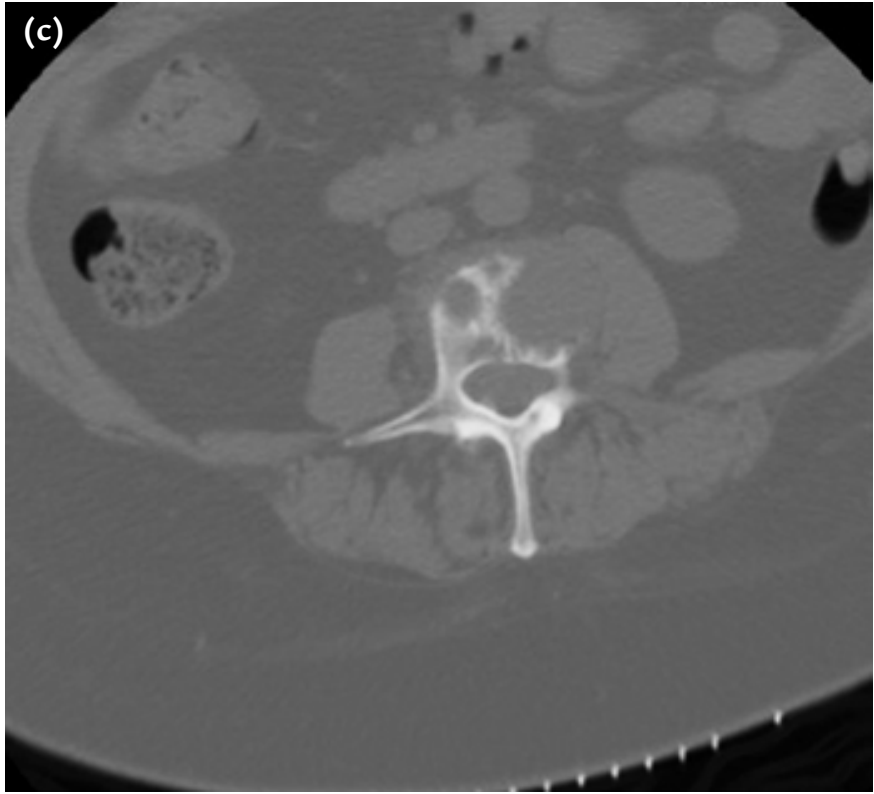

(f)

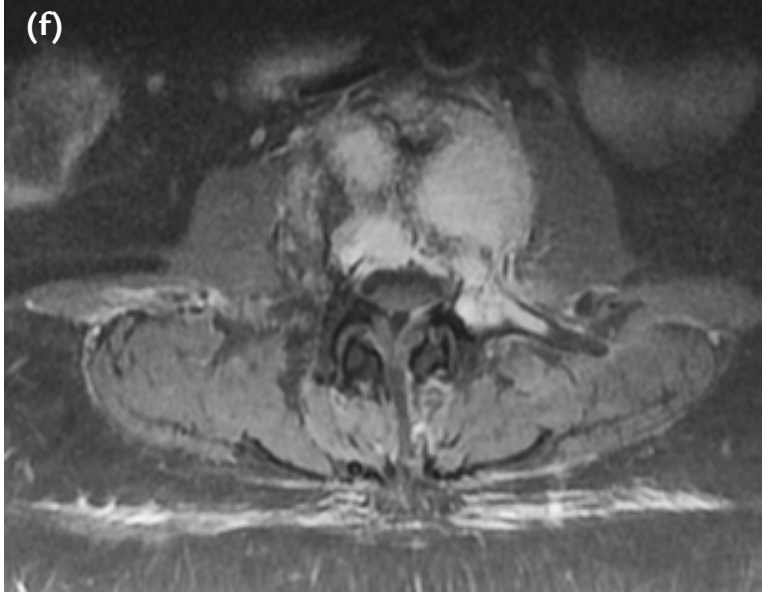

Şekil 2. Bel ağrısı ile başvuran hastada, lumbosakral ön arka ve yan grafilerde dejeneratif spondiloz bulgularına ek olarak, L3 vertebrada yükseklik kaybı dikkati çekmektedir. Aksiyel BT kesitlerinde, korpusta litik karakterde lezyon ve eşlik eden yumuşak doku kitlesigörülmektedir. T2 ağırlıklı sagittal ve aksiyel MR görüntülerinde, omurga cisminden pediküle uzanan hiperintens lezyon dikkati çekmektedir. Biyopsi, karsinom metastazıyla uyumlu bulunmuştur.

\section{GÖRÜNTÜLEME}

Ekstremite kemik sarkomlarının aksine, aksiyel iskelet yerleşimli tümörlerde konvansiyonel radyografi, her ne kadar ilk başvurulması gereken yöntemse de, yeterli bilgi sağlamaz. Konvansiyonel radyografi, omurganın koronal ve sagittal anatomisi ve yapısal bütünlügüunün değerlendirilmesine olanak sağlar. Ancak, litik tümörler, omurga cisminde \%50'nin üzerinde destrüksiyon oluşturana dek radyografide saptanamayabilir. ${ }^{[4,5]} \mathrm{Bu}$ nedenle, klinik olarak malignite şüphesi taşıyan olgularda, radyografi negatif olsa bile bilgisayarlı tomografi (BT) ve manyetik rezonans (MR) görüntülemeye başvurulmalıdır (Şekil 2).
Kortikal destrüksiyonun şiddeti ve boyutları, tümör matriksi ve tümör - sağlıklı kemik geçiş zonunun değerlendirilmesinde, BT ile ayrıntılı veri elde edilebilir. Aksiyel düzleme ek olarak, koronal ve sagittal rekonstrüksiyonları içeren üç boyutlu görüntüleme, kemik tümörlerinde sıklıkla başvurulan bir standarttır.

MR, tümörün yumuşak doku ve nöral yapılara yayılımı, kemik iliği infiltrasyonu ve epidural mesafeye uzanımını mükemmel olarak ortaya koyar. Tümör olgularında kreatinin klirensi kontrol edilerek, kontrastlı (gadolinyum) inceleme yapılması sayesinde, aktivitenin en yoğun olduğu alanlar görüntülenerek, biyopsi için ideal bölge tespit edilebilir. Genel olarak MR, çok 

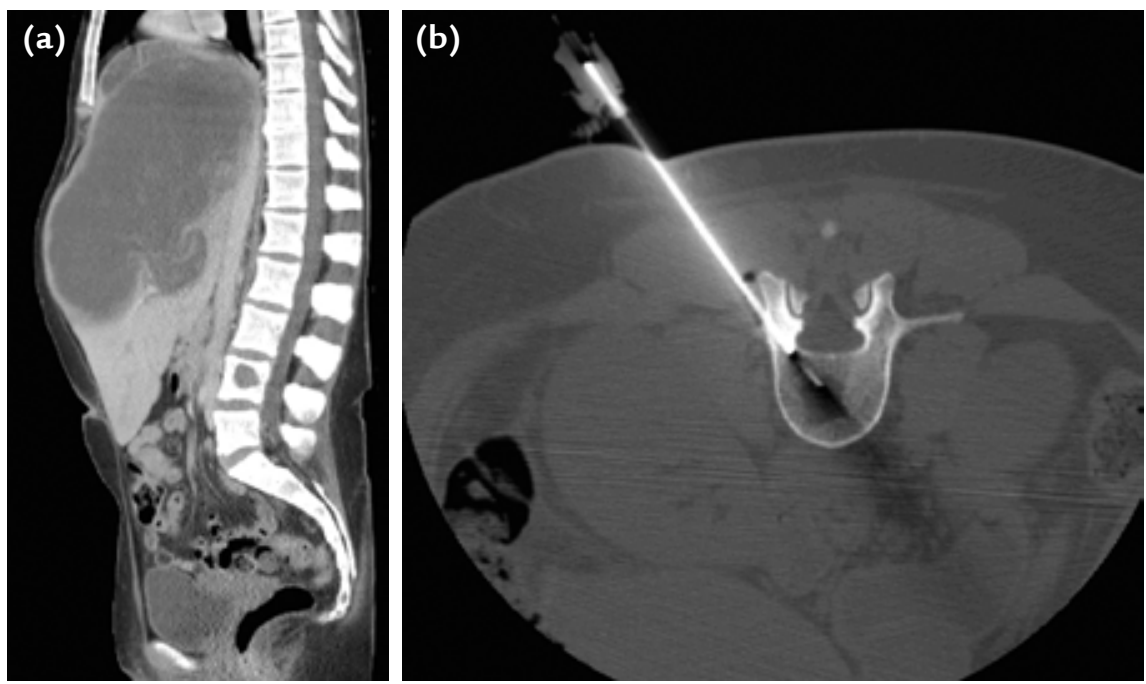

Şekil 3. BT eşliğinde "core-needle" biyopsi, spinal tümör şüphesi olan birçok hastada yeterli sonuç vermektedir. Yukardaki görüntülerde, büyük bir abdominal kitle ve vertebrada litik lezyonla başvuran hastanın evrelemesi amacıyla yapılan perkütan biyopsi görülmektedir.

hassas bir görüntüleme yöntemi olmasına rağmen, tipik spesifik tanıda yardımcı değildir. Bu duruma tek istisna hemanjiyom olabilir. Bu lezyon, T1-2 ağırlıklı görüntülemelerde kemik iliğine yakın sinyal yoğunluğu gösterir. Ayrıca MR, anevrizmal kemik kisti olgularında sıVı-sıvı seviyesini göstermede etkin bir görüntüleme yöntemidir.

Tüm vücut kemik sintigrafisi, özellikle metastatik olgular gibi multipl lezyonların belirlenmesi ve primer tümörlerin evrelenmesi amacıyla, tüm iskeletin taranması açısından rakipsiz bir yöntemdir. Sintigrafi, lezyonun bir ya da birden fazla olup olmadığını ortaya koyarken, eğer varsa biyopsi için daha kolay ulaşılabilir lokalizasyonları gösterebilir. Sintigrafinin multipl miyelom (MM) ve kordomada yalancı negatif sonuç verebileceği unutulmamalıdır. Bu hastalarda, $99 \mathrm{mTc}$ sestamibi daha etkin bir tanı yöntemidir. Sintigrafinin, artmış osteoblastik aktiviteyi gösterirken, malign patolojilerde olduğu gibi benign lezyonlarda da ciddi tutulum göstereceğinden, tanısal değeri sınırlıdır.

Özellikle renal hücreli karsinom, miyelom, tiroid karsinomu gibi maligniteler ya da kemiğin dev hücreli tümörü ya da anevrizmal kemik kisti gibi yüksek vaskülaritesi olan lezyonlarda anjiyografik inceleme ve gerektiğinde, cerrahi öncesi selektif arteriyel embolizasyonla (SAE), cerrahi sırasında kanama önlenebilir ya da azaltılabilir.

Pozitron emisyon tomografisi (PET-CT), primeri bilinmeyen karsinom metastazlarında primer odak tespiti için, yine visseral tutulumun yaygınlığını ortaya koymada ve son olarak, kemoterapi ve radyoterapi alan hastalarda cevabın değerlendirilmesi endikasyonlarıyla kullanılmaktadır.

\section{BIYOPSi}

Biyopsi, özellikle primer spinal tümörleri düşündüren klinik ve radyolojik bulguların varlığında, tanı aşamasındaki en son ve en önemli yöntem olarak karşımıza çıkmaktadır. Yine karsinoma metastazı düşündüren olgularda, bilinen bir odak yoksa, biyopsi ve ardından yapılacak olan immün histokimyasal incelemelerle, primer odak hakkında hızlıca bilgi edinmek mümkün olabilir. Önceden bilinen malignite varlığında, spinal tümörle karşılaşıldığında, klinik ve radyolojik parametreler primer odakla örtüşmüyorsa da, biyopsiye başvurmak gerekir.

Biyopsi öncesi tüm görüntüleme yöntemleri kullanılarak, biyopsi için en uygun omurga segmenti ve ilgili omurgadaki biyopsi hattı belirlenmelidir. Appendiküler iskelette olduğu gibi, başlıca dört biyopsi yöntemi bulunmaktadır; ince iğne biyopsisi, "core-needle" biyopsi, insizyonel ve eksizyonel biyopsi.

Illk ikisi, yani iğne biyopsileri, perkütan uygulanabilen yöntemlerdir. Omurgada ince iğne aspirasyon biyopsisi, yalnızca metastatik olgularda kemik destrüksiyonuna eşlik eden yumuşak doku kitlesi varsa uygulanabilir. Ancak olguların çoğunda, BT eşliğinde "core-needle" biyopsiye gerek duymaktayız. Perkütan biyopsiler, lokal anestezi altında hızlı ve kolay uygulanabilen morbiditesi düşük tanı yöntemleridir. Literatürde, perkütan biyopsilerin \%7090 arasında tanısal doğruluğu olduğu bildirilmektedir.

Kişisel deneyimimiz ışığında, perkütan biyopsilerle, definitif cerrahiyi uygulayacak cerrah tarafından BT eşliğinde bizzat uygulanması koşuluyla, bazı kistik ve düşük gradlı kıkırdak tümörleri dışında, oldukça yüksek oranda tanısal doğruluğa ulaşılabileceğini söylemek mümkündür (Şekil 3). 

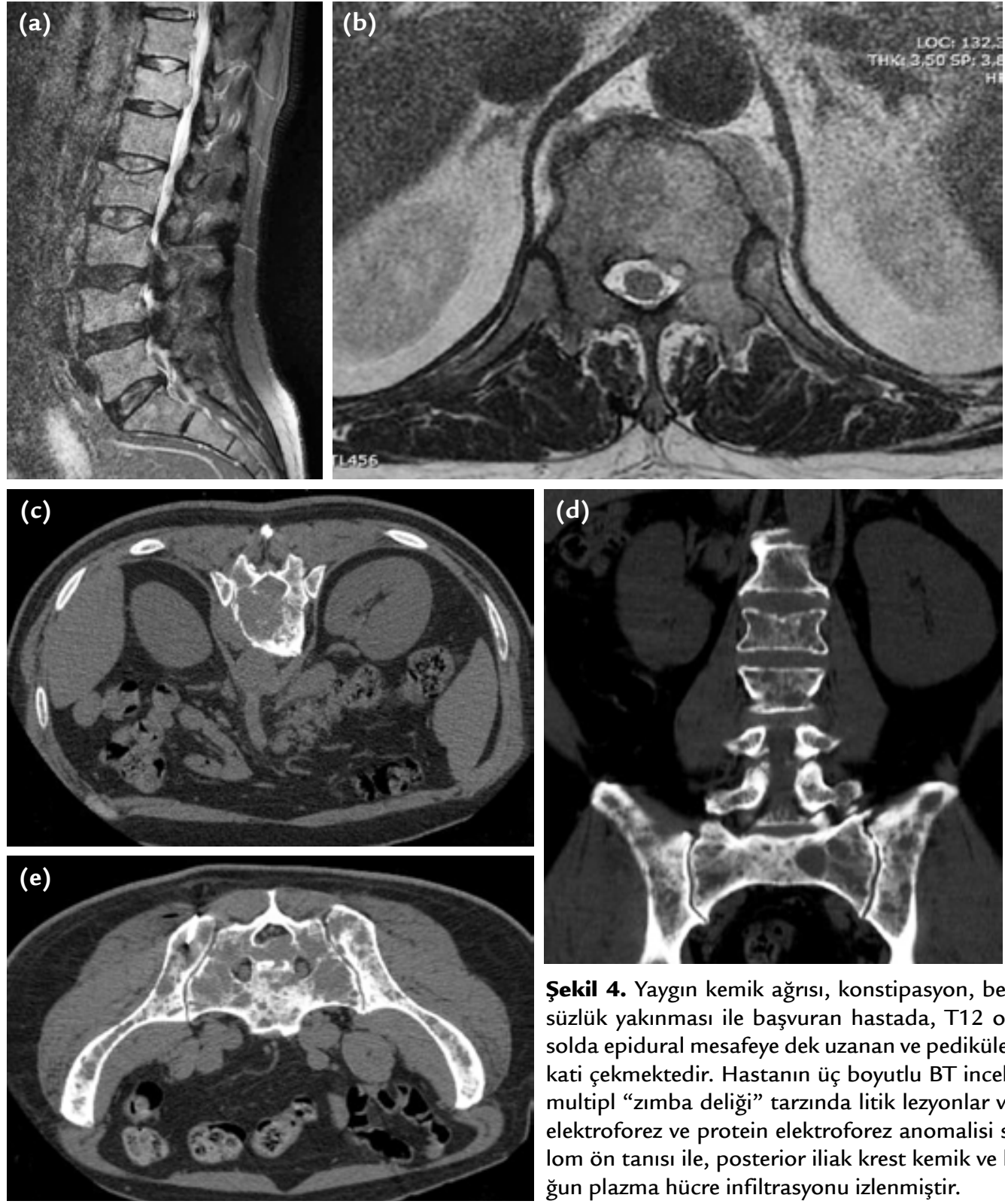

Şekil 4. Yaygın kemik ağrısı, konstipasyon, bel ağrısı ve bacaklarda güçsüzlük yakınması ile başvuran hastada, T12 omurga cisminden başlayıp solda epidural mesafeye dek uzanan ve pediküle ilerleyen tümöral kitle dikkati çekmektedir. Hastanın üç boyutlu BT incelemesinde, tüm kemiklerde multipl "zımba deliği" tarzında litik lezyonlar ve serum analizinde immün elektroforez ve protein elektroforez anomalisi saptanmış ve multipl miyelom ön tanısı ile, posterior iliak krest kemik ve kemik iliği biyopsisinde yoğun plazma hücre infiltrasyonu izlenmiştir.

Perkütan biyopsiler için, sıklıkla $8 \mathrm{G}$ ve $15 \mathrm{~cm}$ uzunluğunda biyopsi iğnesi, transpediküler veya daha nadiren ekstrapediküler yolla yerleştirilmelidir. Görüntüleme eşliğinde bu şekilde alınacak biyopsi, genellikle immün histokimyasal incelemeler dahil yeterli doku örneklemesine izin verir. Daha çok doku örneklemesi gerektirebilecek olgularda, tekrarlayan girişlerle kontaminasyon yaratmak yerine, mevcut iğne içinden daha ince iğnelerle (teleskopik yöntem) örnek almak, yumuşak doku kitlelerinde ise aynı şekilde, örneğin 14G ve 16 $\mathrm{cm}$ bir tru-cut iğneyle seri örnekleme yapmak mümkündür. Biyopsi iğnesi çıkarılmadan önce, kemik iliği aspiratı da alınarak maksimum örnekleme, tek giriş yolundan başarıyla yapılabilir.

Özellikle hematopoietik sistem malignitesi ya da lenfoma düşünülen olgularda, omurga biyopsisi esnasında posterior iliak krestten kemik iliği biyopsisi de yapılması, evreleme aşamasında hastayı basit de olsa ikinci bir cerrahi işlemden kurtarabilecek bir stratejidir (Şekil 4).

Özellikle MR'de görülen ancak BT'de görüntülenemeyen lezyonlarda, MR eşliğinde biyopsi yöntemi uygulanarak daha yüksek tanısal doğruluğa ulaşılabilir. 
Açık biyopsilere, omurgada nadir de olsa, gereksinim duyulabilir. Bu durumda, biyopsi hattının definitif cerrahide çıkarılabilecek boyutta ve lokalizasyonda olması, negatif cerrahi sınır elde edilmesi açısından son derece önemlidir. Açık biyopsi sırasında komşu dokuların kontaminasyonu ve özellikle sakrifiye edilmesi, ciddi morbidite yaratacak nörolojik ve/ veya vasküler yapıların korunması gerekir. Biyopsi işleminde ve sonrasında, hemorajiyle lokal tümör yayılımının engellenmesi amacıyla, dikkatli bir hemostaz yapılmalıdır. Açık biyopsi sırasında oluşturulan kemik pencereleri bone-wax veya kemik çimentosu ile kapatılmalıdır.

Biyopsi sonrası frozen-section ile, aynı cerrahi sırasında definitif cerrahiye geçmek mümkündür. Ancak, bu yöntemi uygulayacak olan patolog, kemik tümörleri konusunda yeterli tecrübeye sahip olmalıdır. Frozensection osteosarkom, Ewing sarkomu ya da kondrosarkom gibi primer malign tümörlerde ve radyolojik olarak atipik yerleşim ve görüntüde olan tümörlerde yetersiz kalacağından, uygulanmamalıdır.

Son olarak; radyolojik ve klinik yöntemlerle benign karakterde olan tipik lezyonlarda (osteoid osteoma, anevrizmal kemik kisti, osteokondrom gibi) eksizyonel biyopsi uygulanabilir. Ancak, geri dönülmez bir tanı ve tedavi hatasından kaçınmak için, cerrahi öncesi radyolojik değerlendirmenin ciddi deneyim gerektirdiği unutulmamalıdır.

\section{EVRELEME VE SINIFLAMA}

Omurga tümörleri başlıca, primer benign, primer malign ve metastatik olarak üçe ayrılır. Appendiküler iskelete benzer şekilde, tümörün histolojik özelliklerine bağlı olarak, kemik tümörleri; osteoblastik (osteoma, osteoid osteoma, osteoblastoma ve osteosarkoma), kondroblastik (osteokondroma, enkondroma, kondromiksoid fibroma ve kondrosarkoma), fibroblastik (nonossifiye fibroma, fibröz displazi, fibrosarkom ve malign fibröz histiyositom), yuvarlak hücreli tümörler

Tablo 1. Enneking sınıflaması

\begin{tabular}{lll}
\hline Evre la & Düşük gradlı, intrakompartmantal & G1T1M0 \\
Evre Ib & Düşük gradlı, ekstrakompartmantal & G1T2M0 \\
Evre IIa & Yüksek gradlı, intrakompartmantal & G2T1M0 \\
Evre IIb & Yüksek gradlı, ekstrakompartmantal & G2T2M0 \\
Evre IIIa & $\begin{array}{l}\text { Düşük ya da yüksek gradlı, } \\
\text { intrakompartmantal + metastazlar }\end{array}$ & G1-2 T1 M1 \\
Evre IIIb & $\begin{array}{l}\text { Düşük ya da yüksek gradlı, } \\
\text { ekstrakompartmantal + metastazlar }\end{array}$ & G1-2T1 M1 \\
&
\end{tabular}

(Ewing/PNET grubu), hematopoietik ve lenfoproliferatif tümörler (lösemi, lenfoma, miyeloma) ve kökeni bilinmeyen lezyonlar (eosinofilik granülom, dev hücreli kemik tümörü) olarak sınıflandırılır.

Enneking, kemik tümörlerini benign ve malign olarak ayırdıktan sonra, benign tümörleri kendi içinde latent, aktif ve agresif olarak üç alt grupta sınıflandırmıştır. ${ }^{[6]}$

Primer malign tümörlerde ise, başlıca üç kriter tanımlanır: $G$, tümörün gradı; $T$, tümörün lokal anatomisi ve metastaz varlığı. Buna göre, malign kemik tümörleri üç ana grupta evrelenir (Tablo 1).

Weinstein-Boriani-Biagini, kemik tümörlerinin temel evrelemesine ek olarak omurgayı, servikal ve torakolomber omurgada primer kemik tümörlerinin anatomik lokalizasyonunu temel alarak, cerrahi planlamaya yönelik olarak, tutulan omurganın aksiyel görüntüsünde dışardan içeri doğru, A'dan (ekstraosseöz yumuşak doku) E'ye (dural tutulum) katmanlar şeklinde ve spinöz çıkıntıdan başlayarak saat yönünün tersine 12 eşit radyal segmente ayırmışlardır. ${ }^{[7]}$

Tomita tarafindan geliştirilen skorlama sistemine göre ise; tümör vertebra cisminde ise Tip1-3, vertebra dışına taşmış ise Tip 4-6 ve diğer vertebraya geçmişse Tip 7 olarak tanımlanmaktadır. ${ }^{[8]}$

Metastatik vertebra tümörlerinde ise, çeşitli algoritmalar kullanılarak, tedavi seçenekleri içinde hangisinin hasta için uygun olduğu belirlenmeye çalışılmaktadır. Temel olarak bu skorlama sistemleri, hastanın genel durumu, primer tümörün davranış özellikleri, sistemik ve lokal yayılım ve nörolojik durum gibi kriterleri ele almaktadır.

\section{CERRAHI TEDAVi}

Ekstremite yerleşimli kemik tümörlerinde rezeksiyon seçenekleri, sırasıyla, intralezyonel (tümör dokusuna bilerek ya da istemeyerek girilmesi ve tümörün parçalar halinde çıkarılması; gross kontaminasyon), marjinal (tümör - sağlıklı kemik geçiş zonunda çalışılarak tümörün çıkarılması; mikroskopik rest olasılığı), geniş (tümör çevresinde bir miktar sağııkı doku bırakılarak yapılan rezeksiyon) ve radikal (tüm kompartmanın çıkarılması) olarak ayrılmaktadır. Ancak, omurgada radikal rezeksiyon, spinal kordun sakrifiye edilmesini gerektireceğinden uygulanabilir değildir (Şekil 5). ${ }^{[4]}$

İntralezyonel rezeksiyon, lokal nüks olasılığı düşük benign ya da lokal agresif tümörlerde tercih edilirken; malign kemik tümörlerinde ideal cerrahi, geniş rezeksiyondur. Ancak yine omurgada, tümörün anatomisi ve vital yapılarla ilişkisi, özellikle geç kalınmış ve ciddi yayılım göstermiş olgularda, geniş rezeksiyona izin vermeyebilir. 


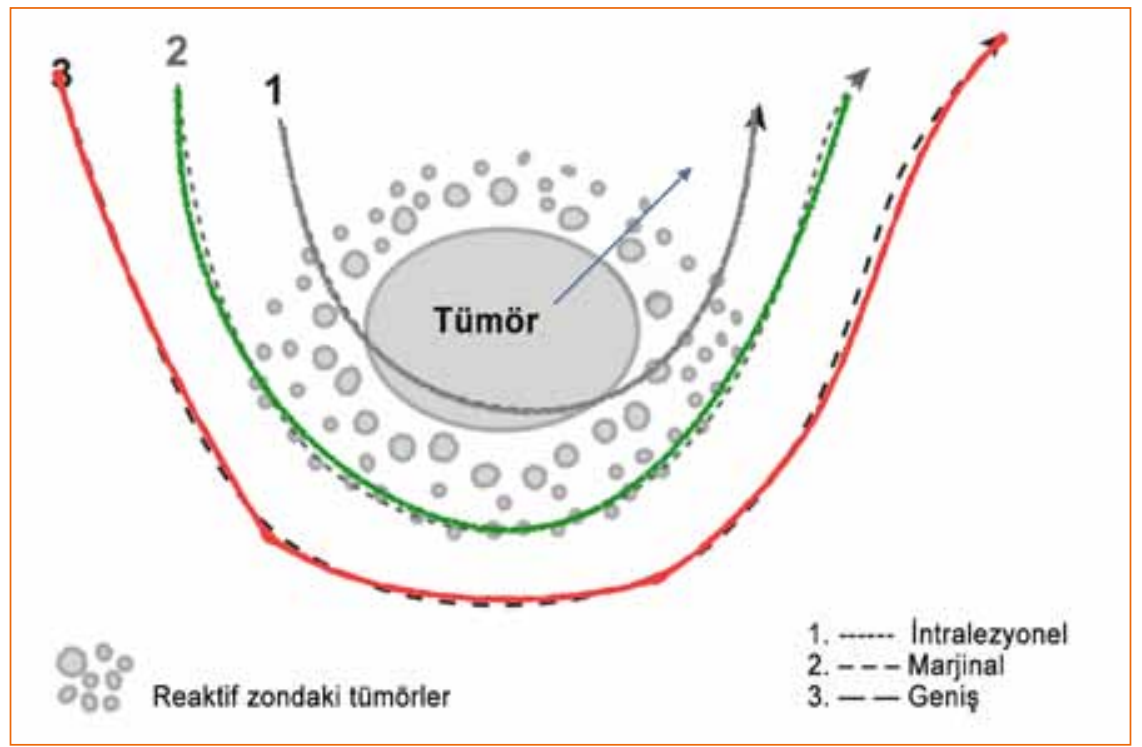

Şekil 5. Tümör cerrahisinde rezeksiyon tipleri.

\section{OMURGADA SIK GÖRÜLEN PRIMER KEMIK TÜMÖRLERI}

Primer kemik tümörleri, nadir görülür ve tüm omurga tümörlerinin \%5'ini oluşturur. Özellikle primer malign tümörlerde, metastatik lezyonlardan farklı olarak tek lokalizasyonda görüldüklerinden, tanı ve tedavide erken ve doğru yaklaşım ile kür potansiyeli düşük değildir. Maalesef birçok hasta, geç tanı ya da uygun olmayan tedaviler nedeniyle tedavi şansını kaybetmektedir. Tüm omurga neoplazmları içinde, özellikle çocuk ve genç erişkinlerde sık görülen bu tümörler, ayırıcı tanı açısından en önemli grubu oluşturmaktadır (Tablo 2 ve 3 ).

\section{Osteoblastik Tümörler}

\section{Osteoid Osteoma ve Osteoblastoma}

Osteoblastik tümörler grubundaki benign tümörlerden; osteoid osteoma ve osteoblastoma, sıklıkla genç erişkinlerde görülen, lameller yapıda, iyi diferansiye, olgun kemik dokusu oluşturan ve yavaş büyüme gösteren lezyonlardır. Bu lezyonların görüntüleme özellikleri genellikle karakteristiktir.

Omurgada ağrıya bağlı skolyozun en sık nedenlerinden olan osteoid osteoma ve osteoblastoma, histolojik olarak benzer görünümde, fakat boyutları, yerleşim yerleri ve klinik bulguları farklı olan lezyonlardır. Osteoid osteoma, sıklıkla intrakortikal yoğun sklerotik halka ile çevrili küçük radyolusen lezyon olarak görülür. Skleroz nedeniyle büyük görülse de, boyutları nadiren $1,5 \mathrm{~cm}$ 'yi geçer. Nonsteroidlere yanıt veren gece ağrısı, tipik klinik bulgusudur. Tedavide; medikal, açık cerrahi ve perkütan yöntemler olmak üzere üç temel farklı yaklaşım mevcuttur (Şekil 6).

Osteoblastoma, omurgada sıklıkla posterior elemanları tutar. Benign histolojiye rağmen bazen agresif davranış gösterebilir. Nadiren de olsa, malign dönüşüm bildirilmiştir. Genellikle bir matür kemik tarafından çevrili, kalsifikasyonlar içeren, sıklıkla ekspansil, yer yer radyolusen ve yer yer blastik karakterde bir lezyondur. Karakteristik semptomu lokalize ve nonsteroidlere yanıtı osteoid osteomaya göre daha az olan, künt bir ağrıdır.

Tedavide, intralezyonel küretaj ilk seçenektir, ancak nüks olgularda ya da ileri derecede agresif lezyonlarda veya sakrifiye edilebilen yapıları tuttuğunda, geniş rezeksiyon gerekli olabilir.

Osteoid osteoma ve osteoblastomaya bağlı skolyoz, postüral bir skolyoz olmasına karşın, matürite öncesi olgularda ve özellikle semptomların başlaması ve tedavi arasında geçen süre uzun ise, strüktürel skolyoza dönüşebilir. Bu nedenle, cerrahi tedavinin kısa sürede yapılması gerekir. ${ }^{[9]}$

Osteosarkom, osteoblastik karakterde bir tümördür ve en sık görülen primer malign kemik tümörüdür, ancak spinal lokalizasyonu tüm osteosarkomlar içinde \%3-5 oranındadır. Sıklıkla adolesan ve genç erişkin yaş grubunda görülür ve erkeklerde biraz daha sıktır. Omurgada, en sık sakrum ve lumbosakral, daha sonra lomber ve torakal bölgede tutulum görülür. 
Tablo 2. Vertebra tutulumlu benign tümörler

\begin{tabular}{|c|c|c|c|c|}
\hline Lezyon & Yaş & Lokasyon & Klinik & Radyolojik \\
\hline Osteoid osteoma & $20-40$ & $\begin{array}{l}\% 75 \text { Posterior } \\
\text { (Lamina) }\end{array}$ & Gece ağrısı, aspirine yanıt & $\begin{array}{l}\text { BT'de skleroz ve nidüs formasyonu, } \\
\text { Skolyoz, Target sign }\end{array}$ \\
\hline Osteoblastoma & $20-30$ & $\begin{array}{l}\text { Posterior } \\
\text { (Lamina) }\end{array}$ & Ağrı ve radikülopati & Destrüktif lezyon, kemikte ekspansiyon \\
\hline Osteokondrom & $30-40$ & $\begin{array}{l}\text { Posterior } \\
\text { (Spinal proçes) }\end{array}$ & Şişlik ve bası semptomları & $\begin{array}{l}\text { Kaynaklandığı kemikten kesintisiz olarak } \\
\text { devam eden korteks ve kemik iliği }\end{array}$ \\
\hline Hemanjiyom & $40-50$ & $\begin{array}{l}\text { Anterior } \\
\text { (Korpus) }\end{array}$ & $\begin{array}{l}\text { Lokal ağrı, Geniş tutulumda vertebrada } \\
\text { çökmeye sekonder paraparezi. }\end{array}$ & $\begin{array}{l}\text { Trabeküllerde kalınlaşma ve genişleme, } \\
\text { vertebrada çökme, MRG'de artmış sinyal }\end{array}$ \\
\hline Anevrizmal kemik kisti & $10-20$ & $\begin{array}{l}\% 60 \text { posterior, } \\
\% 40 \text { anterior }\end{array}$ & Ağrı & Litik ekspansil lezyon, sıvı-sıvı seviyesi \\
\hline Eozinofilik granülom & $10-30$ & Sıklıkla anterior & İlerleyici sırt ağrısı & $\begin{array}{l}\text { Litik lezyon, vertebra cisminde çökme } \\
\text { (vertebra plana) }\end{array}$ \\
\hline Dev hücreli tümör & $20-40$ & Anterior & Ağrı ve radikülopati & $\begin{array}{l}\text { Vertebra korpusunda genişleme ve } \\
\text { radyolusen alanlar. }\end{array}$ \\
\hline
\end{tabular}

Tablo 3. Vertebra tutulumlu malign tümörler

\begin{tabular}{|c|c|c|c|c|}
\hline Lezyon & Yaş & Lokasyon & Klinik & Radyolojik \\
\hline Osteosarkom & $40-50$ & Anterior & $\begin{array}{l}\text { Ağrı, palpe edilebilir kitle, nörolojik defisit, } \\
\text { genel durum bozukluğu }\end{array}$ & $\begin{array}{l}\text { Kortikal destrüksiyon, Yumuşak doku } \\
\text { kalsifikasyonu, periost reaksiyonu }\end{array}$ \\
\hline Kondrosarkom & $50-60$ & Anterior & Ağrı, palpe edilebilir kitle, nörolojik defisit & Litik, destrüktif lezyon, noktasal kalsifikasyon \\
\hline $\begin{array}{l}\text { Malign fibröz } \\
\text { histiyositom }\end{array}$ & $20-80$ & Anterior & Ağrı, palpe edilebilir kitle, nörolojik defisit & $\begin{array}{l}\text { Litik lezyon, yumuşak doku kitlesi, T1'de düşük, } \\
\text { T2'de yüksek sinyal }\end{array}$ \\
\hline Multipl miyelom & $40-60$ & Anterior & $\begin{array}{l}\text { Özellikle gece artan bel ağrısı, } \\
\text { genel durum bozukluğu, bozulmuş kan tablosu }\end{array}$ & $\begin{array}{l}\text { Diffüz osteopeni, zımba deliği şeklinde litik } \\
\text { lezyonlar, T1'de hipo T2'de hiperintens }\end{array}$ \\
\hline Ewing sarkomu & $20-40$ & Anterior & Ağrı, nörolojik defisit & Litik lezyon, yumuşak doku kitlesi \\
\hline Kordoma & $30-50$ & Anterior & $\begin{array}{l}\text { Giderek artan ağrı, konstipasyon, } \\
\text { nörolojik defisit }\end{array}$ & $\begin{array}{l}\text { Orta hatta destrüktif ekspansil kitle, Komşu } \\
\text { vertebraya uzanım }\end{array}$ \\
\hline Lenfoma & $40-60$ & Anterior & Ağrı, nörolojik defisit, genel durum bozukluğu & Litik lezyon \\
\hline Metastaz & $40-60$ & Anterior & Ağrı, nörolojik defisit, genel durum bozukluğu & Litik lezyon, patolojik kırık, deformite \\
\hline
\end{tabular}
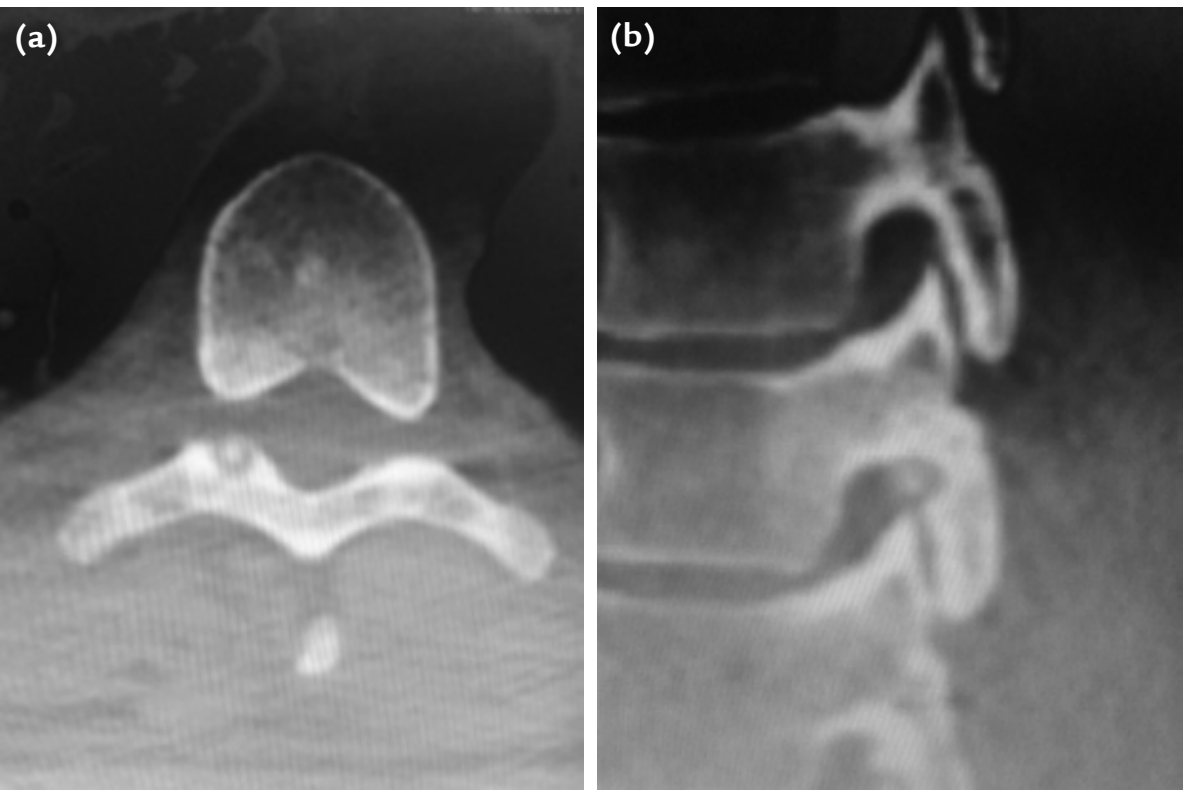

Şekil 6. Vertebral foramene yakın komşulukta osteoid osteoma. Spinal korda oldukça yakın bir lezyon olması nedeniyle, tedavide perkütan yöntemler yerine açık rezeksiyon tercih edilmelidir. 

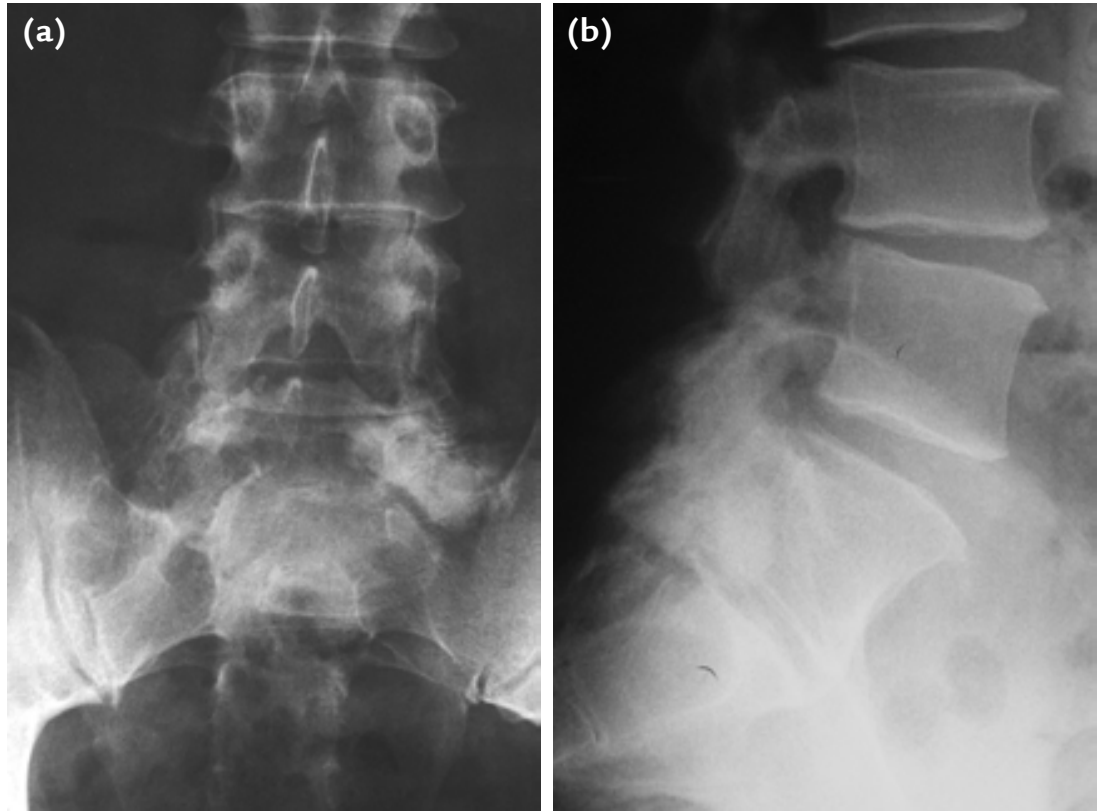

Şekil 7. Bel ve bacak ağrısıyla başvuran hastada, konvansiyonel radyografide, L5S1 faset eklemi çevresinde lokalize osteodansite izlenmektedir. Hastanın aksiyel BT görüntüsünde, S1 vertebra korpusundan pediküle uzanan ve bu seviyede kord basısına yol açan, yumuşak doku yayılımı gösteren, osteoblastik karakterde, düzensiz sınırlı kitle dikkati çekmektedir. Biyopsi, osteosarkomu teyit etmiştir.
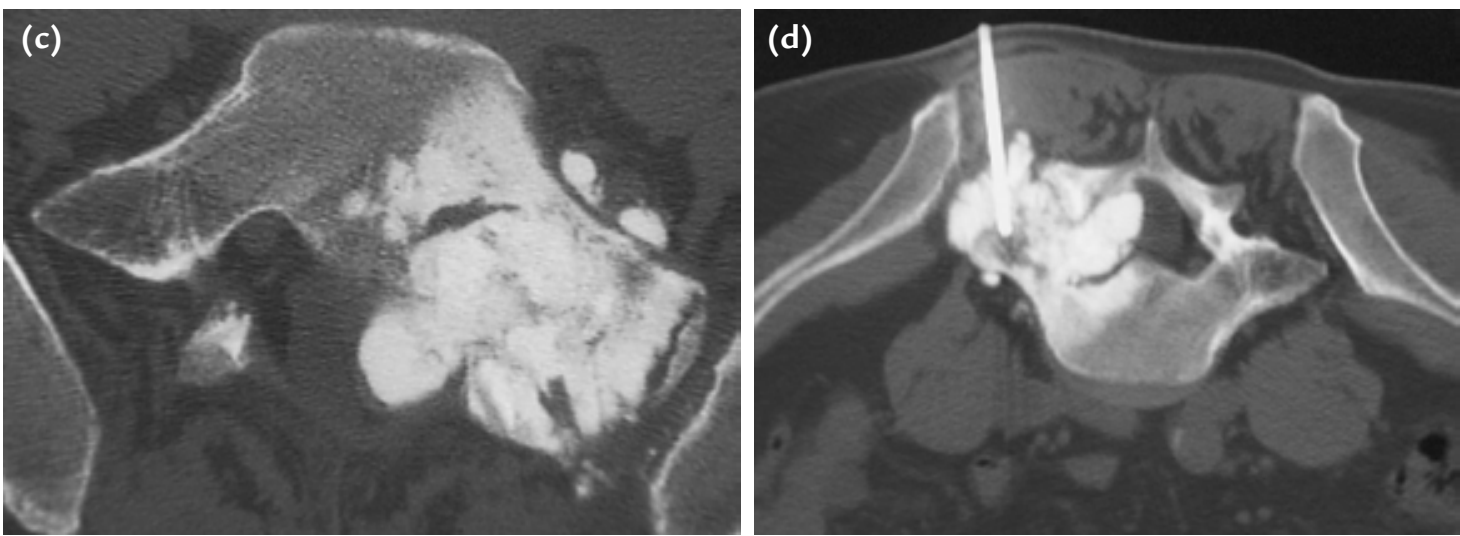

Histolojik olarak osteosarkom, bağ dokusunun osteoid üreten malign tümörü olarak değerlendirilir. Ekstrasellüler matriksi, tümörün diferansiyasyonuna bağlı olarak farklılık gösterebilir. Osteosarkomun, osteoblastik ve kondroblastik alt tiplerine ek olarak, daha nadir görülen, yuvarlak hücreli, telenjiektazik ve fibroblastik tipleri vardır. Birçok tümörde baskın bir patern olmasına karşın, mikst bir görünüm de dikkati çeker.

Osteosarkom, tümörün gradına bağlı olarak, düşük, orta ve yüksek gradlı olarak sınıflandırılır. Yine yerleşim olarak, klasik intramedüller tipler, yüzey osteosarkomları, periosteal ve parosteal osteosarkom tipleri vardır. Tüm osteosarkomlar içinde olguların büyük çoğunluğu, klasik yüksek gradlı osteosarkomdur.

Radyolojik olarak osteosarkom, kemik üreten bir tümör olduğundan, blastik ve litik alanların görüldüğü heterojen ve düzensiz bir kitle olarak karşımıza çıkar. Omurgada, BT konvansiyonel radyografi ile birlikte değerlendirilerek, kortikal destüksiyon, tümör matriksi ve tümör-sağlıklı kemik geçiş zonu incelenmelidir.

Olguların önemli bir kısmında, tümörün intramedüller ve çevre yumuşak doku yayılımı sözkonusu olduğundan, MR ile medüller kanalın değerlendirilmesi gerekir. Ancak, osteosarkomun MR bulguları oldukça nonspesifiktir. Osteoid içeren alanlar düşük sinyal ile karakterize olurken, özellikle telenjiektazik osteosarkomda, sıvı dolu kistik alanlar, yüksek sinyal içeren alanlar olarak dikkati çeker.

Sintigrafide osteoblastik bir lezyon olan osteosarkom, yoğun artmış aktiviteyle kendini gösterir. Sintigrafi, ayrıca, diğer kemiklerde bir metastatik ya da multipl odak olup olmadığını da ortaya koyar (Şekil 7). 
Görüntüle yöntemleri tamamlandığında, histolojik tanı amacıyla biyopsi yapılmalı ve lezyonun tipi ve gradı belirlenmelidir. Osteosarkomda nadir görülen low-grade osteosarkomlar dışında, neoadjuvan (cerrahi öncesi) multi-ajan kemoterapi standarttır. Cerrahi öncesi üç kür, kemoterapiyi takiben lokal ve sistemik evreleme tekrarlanarak, tümör tekrar değerlendirilir. Cerrahi tedavide, tümörün geniş rezeksiyonu tek ve en geçerli yöntemdir. Geniş rezeksiyon sonrası lokal nüks oranı \%20'lerde iken, intralezyonel rezeksiyonda bu oran \%60'lara çıkabilmektedir. Lokal nüksün, metastaz ve mortalite riskini ciddi olarak arttıracağı unutulmamalıdır. ${ }^{[10]}$

Bununla birlikte, tümörün anatomik yerleşimi, anteriordeki majör vasküler yapılara yakınlığı ve posteriorda nöral elemanlarla olan ilişkisi nedeniyle, geniş rezeksiyonun başarılamadığı durumlarda, intralezyonel rezeksiyon gündeme gelebilir.

Cerrahi tedavi sonrası, adjuvan kemoterapiyle tedavinin tamamlanması gerekir. Osteosarkom, genel olarak radyorezistan bir tümör olarak kabul edilir. Radyoterapi, ancak cerrahi tedavisi mümkün olmayan, nüks ve kemoterapi yanıtı kötü olan olgularda uygulama alanı bulur.

Genel olarak, omurga osteosarkomunda, nonmetastatik hastalarda beş yıllık sağkalım \%40'lar civarındadır. Bu, ekstremite osteosarkomundan daha düşüktür. Olguların, bu konuda deneyimsiz cerrahlarca, neoadjuvan kemoterapi uygulanmadan ya da tümör cerrahisi prensiplerine bağlı kalınmaksızın tedavi edilmeye çalışılması, bu oranı çok daha ciddi oranda düşürecektir.[10,11]

\section{Kondroblastik Tümörler}

\section{Osteokondrom}

Osteokondromlar, sık görülen kemik hamartomlarıdır. Başlıca, herediter multipl ve soliter tipleri vardır. Osteokondromların tipik makroskopisi, kemik bir sap ya da gövdenin üzerine oturan kıkırdak şapka şeklindedir. Epifız büyüme plağının kapanmasını takiben, osteokondromların da büyümesi durur. Omurga yerleşimli osteokondromlar nadir görülür ve sıklıkla ağrısı kitleler olarak ortaya çıkar. Daha çok servikal ve üst torasik omurgada rastlanır; lomber omurga tutulumu daha nadirdir. Osteokondromların, herediter tipinin yaklaşı $\% 5-10$, soliter tipinin ise \%1 malign transformasyon gösterebileceği düşünülmektedir. Erişkin bir hastada varolan bir osteokondromun boyutunda artış ve ağrı, radyolojik değerlendirmede kıkırdak şapkada büyüme varsa $(>1 \mathrm{~cm})$, kondrosarkom gelişimi açısından şüphe uyanmalı ve biyopsi yapılmalıdır.

\section{Kondrosarkom}

Malign kıkırdak tümörü olan kondrosarkom, tüm primer kemik tümörlerinin yaklaşık \%10'unu teşkil eder. Low-grade lezyonlar, genellikle önceden varolan bir enkondrom ya da osteokondromun malign transformasyonu şeklinde ortaya çıkar. Kondrosarkomların \%10'dan azı omurga yerleşimi gösterir. Sıklıkla torasik ve lomber bölgede yer alır. Özellikle low-grade kondrosarkomlarda lezyon, tanıdan önce oldukça büyük boyutlara ulaşabilmektedir.

Tümör, daha çok erkek hastalarda ve orta ileri yaşta sıktır. Histolojik olarak, kondrosarkomlar osteosarkomlar gibi düşü̈k, orta ve yüksek gradlı tümörler olarak sınıflandırılır. Buna ek olarak, mezenkimal, berrak hücreli ve dediferansiye kondrosarkom tipleri de vardır.

Radyolojik olarak kondrosarkom, kalsifikasyonlar veya ossifikasyonlar içeren destrüktif lezyonlar olarak kendini gösterir. Birçok olguda, özellikle yüksek gradIı lezyonlarda, yumuşak doku komponenti de eşlik eder. ${ }^{[12,13]}$

Kondrosarkomların enkondromlardan ayırt edilmesi, önemli bir klinik sorundur. Enkondromlar genellikle insidental saptanan lezyonlar olmalarına karşın, kondrosarkomlar ağrı ve/veya bası semptomları ile kendini gösterir. Radyolojik olarak enkondromlar, matür kalsifiye veya kıkırdak içeren lezyonlar ile karakterizedir. Bir kıkırdak tümöründe, kortekste "scalloping" ve destrüksiyon, matriks içinde artmış heterojenite ve yumuşak dokuya uzanım gibi bulgular varsa, malign transformasyondan şüphe etmek gerekir. Radyolojiye ek olarak, düşük gradlı kıkırdak tümörlerinin patolojik tanısı da sorunludur. Deneyimli patologlar arasında bile, lezyonun gradı konusunda görüş birliği olmadığı gösterilmiştir. Bu nedenle, benign/malign ayrımı yaparken, klinik, radyoloji ve patoloji birlikte değerlendirilmelidir.

Diğer primer malign tümörlerde olduğu gibi, kondrosarkomlar da geniş cerrahi eksizyonla tedavi edilmelidir. Kondrosarkomlar, gerek kemoterapiye gerekse radyoterapiye dirençli tümörlerdir.

\section{Benign Lokal Agresif Tümörler}

\section{Anevrizmal Kemik Kisti (AKK)}

AKK, tümör benzeri lezyonlar grubundandır. Omurgada, özellikle genç hastalarda görülür; sıklıkla posterior elemanları tutar ve bazen büyük boyutlara ulaşıp vertebra cismine doğru uzanım gösterebilir. Konvansiyonel radyografide, sklerotik bir kemikle çevrili litik bir kavite saptanır. BT ve MR, lezyon içindeki septalarla ayrılmış kan dolu boşlukları (sıvı-sıvı seviyeleri) ortaya koyar. Bu görünüm, AKK için tipiktir. 
Lezyon çevresindeki kemik korteks oldukça incedir ve balonlaşma gösterir. AKK, oldukça vasküler bir lezyondur. Bu nedenle, aşırı hemorajiden kaçınmak için, lezyonun selektif arteriyel embolizasyon (SAE)'u yapılmalıdır. Birçok hastada, tekrarlayan embolizasyonlarla kistin küçülmesi ve ossifikasyonu sağlanabilmektedir. Ancak, en az iki SAE uygulamasına rağmen büyüme gösteren olgularda, patolojik kırık ya da kırık riski varsa veya nörolojik tutulumla seyreden olgularda, intralezyonel küretaj uygulanmalıdır. Vertabra stabilizasyonunun etkilendiği durumlarda, stabilizasyona yönelik girişimler gerekli olabilir. ${ }^{[14,15]}$

\section{Dev Hücreli Kemik Tümörü (DHKT)}

DHKT, histolojik olarak benign ancak klinik olarak bazen malign davranabilen bir lezyondur. Nüks oranı, diğer benign tümörlerle kıyaslandığında, belirgin olarak yüksektir ve nadiren de olsa olguların \%5'inde akciğer metastazları görülebilir. Ekstremite yerleşimli DHKT ile kıyaslandığında, omurga yerleşimli olguların akciğer metastazları daha mortal seyreder.

Lezyon, daha çok genç erişkinlerde (2.-4. dekadlar arası) görülür. Radyolojik olarak, tümüyle litik destrüktif karakterdedir. Histolojik olarak, arka planda mononükleer ve iğsi hücrelerin oluşturduğu bir stroma içinde multi-nükleer dev hücreli tümörlerin oluşturduğu bir görünüm vardır.

Omurgada, sıklıkla torasik, lomber ve servikal yerleşim gösterir. Ekstremitede olduğu gibi, DHKT içinde sekonder AKK görülebilmektedir. Omurga yerleşimli DHKT'de tedavi, ekstremite yerleşimli lezyonlara göre güçlük arzeder. Birçok tümör ileri evrededir (Evre 3) ve omurgadaki vital yapılarla yakın ilişkidedir. Lokal nüksle gelen olgularda, cerrahi tedaviye bağlı morbidite oldukça yüksek olduğundan, ilk tedavinin planlı ve doğru yapılması ciddi önem arzeder.

Evre 2 tümörlerin, intralezyonel genişletilmiş küretajla tedavisi sonrası nüks oranı, Evre 3 tümörlere göre daha düşüktür. Bu nedenle, tümörün anatomisi izin veriyorsa, Evre 3'te geniş rezeksiyon uygulanmalıdır. AKK gibi dev hücreli tümör de oldukça vasküler bir lezyondur ve cerrahi tedavi öncesi SAE rutin uygulanmalıdır.

Birçok merkez, cerrahi tedavi sonrası adjuvan radyoterapiyi önermektedir. Ancak, radyoterapinin tek modalite olarak uygulanması tartışmalı bir konudur. Bazı merkezler küratif radyoterapiyle oldukça başarılı sonuçlar bildirirken, diğerleri radyoterapinin tek başına yeterli olmadığını belirtmektedir. ${ }^{[14,16]}$

Son yıllarda, bir RANKL inhibitörü olan denosumabla, ekstremite olgularına benzer şekilde, omurga DHKT'de başarılı sonuçlar yayımlanmaktadır. ${ }^{[17,18]}$
Akciğer metastazı ile seyreden olgularda nadiren spontan regresyon bildirilmekle birlikte, tedavi seçeneği tümörün rezeksiyonudur. Buna rağmen, olguların dörtte biri fatal seyretmektedir. ${ }^{[19]}$

\section{Yuvarlak Hücreli Tümörler}

\section{Ewing Sarkomu ve Primitif Nöroektodermal Tümörler}

Ewing sarkomu, çocukluk çağı küçük yuvarlak mavi hücreli malign tümörlerinin prototipidir. Osteosarkomdan sonra en sık görülen, ikinci primer malign kemik tümörüdür. Yaklaşık milyonda iki sıklıkta görülür. Tümör, daha çok çocuklar ve genç erişkinlerde ortaya çıkar. Omurga yerleşimli olgularda, tümörün hızlı ve büyük yumuşak doku komponenti nedeniyle, kord basısı ve nörolojik semptomlar sık görülür (Şekil 8).

Omurgada sakrum, en sık görülen lokalizasyondur ve sakral kitleler genellikle çok büyük boyutlara ulaşır. Ewing sarkomu, radyolojik olarak litik destrüktif güve yeniği/permeatif bir lezyon olarak görülür. Sakrumda, destrükte kemik buzlu cam görüntüsü verebilir. Ekstremitede olduğu gibi, sakrum ve lumbosakral yerleşimli lezyonlarda yumuşak doku komponenti, tanıdan önce çok büyük boyutlara ulaşabilir.

Sistemik multi-ajan kemoterapi, Ewing sarkomunda oldukça etkilidir. Neoadjuvan kemoterapi sonrasında birçok hastada, rezeksiyonu mümkün olmayan tümörler, rezeke edilebilir duruma gelir. En-blok rezeksiyon, diğer malign tümörlerde olduğu gibi Ewing sarkomunda da tek geçerli cerrahi yöntemdir. Bununla birlikte, ekstremite yerleşimli lezyonların aksine, omurga yerleşimli Ewing sarkomunda cerrahi her zaman mümkün olmayabilir. Bu hastalarda lezyonun radyosensitif olması nedeniyle, küratif dozlarda radyoterapi uygulanmaktadır. ${ }^{[12,20]}$

\section{Notokord Kökenli Tümörler}

\section{Kordoma}

Kordoma, notokord kökenli nadir bir kemik tümörüdür. Tüm kemik tümörlerinin \%5'inden azını oluşturur. Kordoma, yavaş geliş̧mekle birlikte, lokal agresif bir tümördür, ancak metastaz potansiyeli de düşüktür. Kordomaların yıllık inisidansı milyonda $0,8 /$ yıl olarak bildirilmektedir. Hastaların büyük çoğunluğu 40 yaşından büyüktür. Olguların \%62'si omurga ve sakrum yerleşimlidir.

Sakral kordomalarda bulgular geç ortaya çıkar. Nonspesifik ağrı, ilk semptomdur. Buna ek olarak, hastaların \%40'ı rektal disfonksiyon (kabızlık, tenezmus) tanımlarlar. Lomber omurga tutulumu gösteren olgularda ise, tümör daha küçük boyutlardayken, bel ağrısı ve hastaların üçte ikisinde radiküler bulgular görülür. 

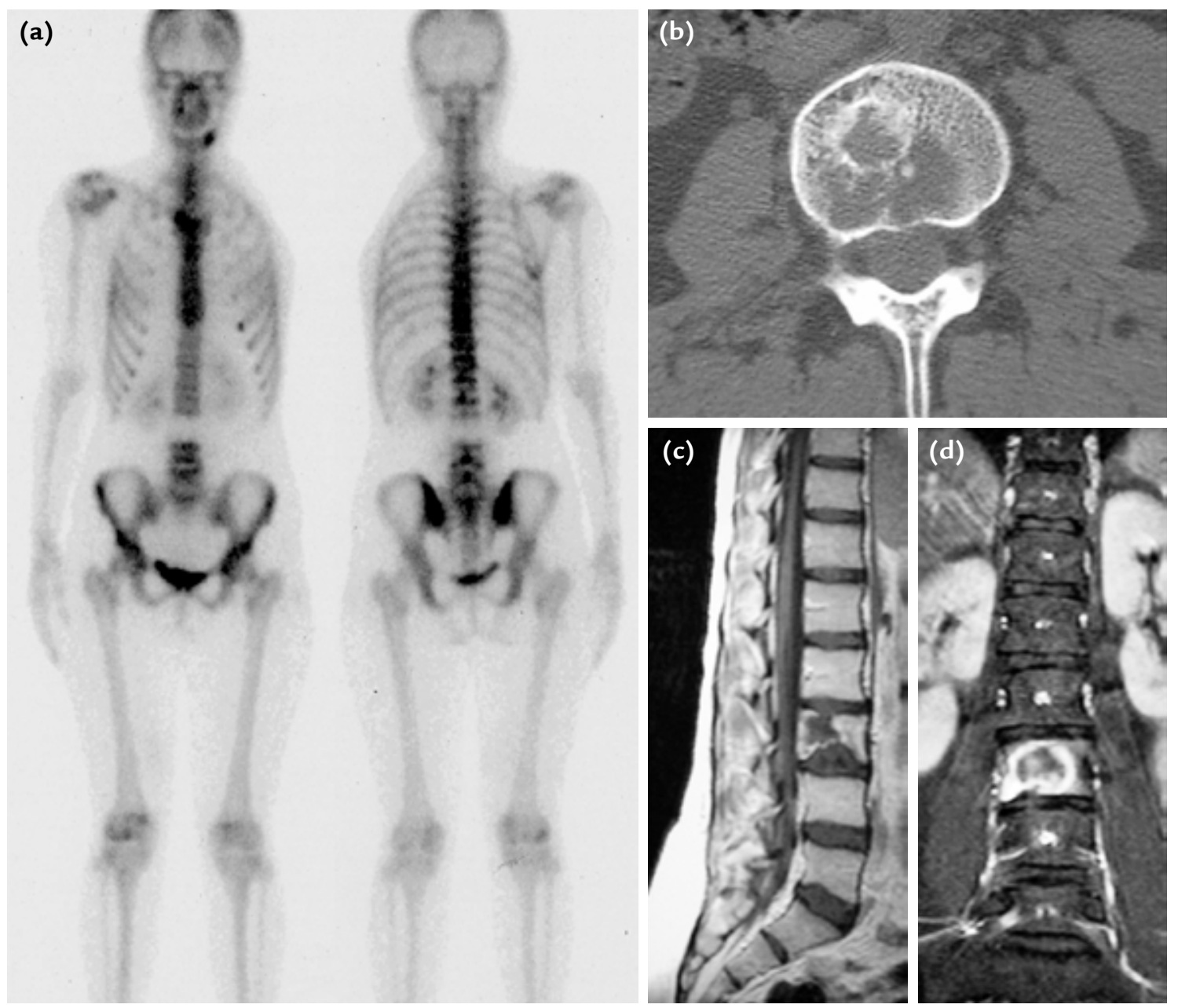

Şekil 8. Bel ağrısıyla başvuran hastanın MR görüntülerinde, L3 vertebrada T1 ağırlıklı sagittal sekanslarda, düşük sinyal ağırlıklı T2 kontrastlı koronal sekansta, merkezde düşük (nekroz), periferde yüksek sinyal gösteren, patolojik kırığın eşlik ettiği lezyon. Lezyon, sintigrafide osteoblastik aktivite göstermemektedir (agresif yuvarlak hücreli tümör). Patoloji, Ewing sarkomla uyumlu bulunmuştur.

Tümör, büyük çoğunlukla ekstrakompartmantaldir; $B T$ ve $M R$, tümörün yayılımını net olarak gösterir. $M R$, özellikle T2-ağırlıklı sekanslar, tümörün rektumla olan ilişkisini, nöral kanalın durumunu, lateral ve posterior yaygınlığını, net olarak gösterir.

Makroskopik olarak kordomalar, lobüle, gri saydam kistik ve solid alanlar içeren lezyonlar şeklindedir. Tümör, bazen ossifiye ya da kalsifiye bir kitle kadar sert bazen de oldukça yumuşak kıvamdadır. Sakral bölgede anteriordaki periost eleve olarak, bir yalancı kapsül görünümü alır. Ancak, kemiğin içinde bir sklerotik zone genellikle yoktur.

Mikroskopik olarak tümör, lobüler yapıda, inkomplet ve lenfositlerle infiltre fibröz septalarla ayrılmış "sabun köpüğü" hücrelerden oluşur. Ancak, bazı olgularda iğsi sarkom benzeri hücreler görünümünde, bazen de yuvarlak hücre ya da epitelyal komponent şeklinde oldukça farklı görünümlerde olabilir.

Günümüzde kordomaların tedavisi, en-blok rezeksiyondur. Sakral bölgede tümörün anatomik yayılımına bağlı olarak, posterior, anterior ya da kombine yaklaşımlar gerekli olabilir. Özellikle S2-S4 arası sakral köklerin bilateral sakrifye edilmesi gereken olgularda, hastalar, kalıcı mesane barsak ve seksüel disfonksiyonla karşılaşacakları konusunda bilgilendirilmelidir. Ilk sakral omurga ve üzerindeki lezyonlarda, total sakrektomi ve lumbopelvik tespit gereklidir.

Vertebra cisminde yerleşen kordomalarda, total enblok korpektomi en geçerli seçenektir. Bu cerrahi, önce posterior stabilizasyon, ardından aynı seansta ya da evrelenerek, anterior rezeksiyon ve rekonstrüksiyonla uygulanır (Şekil 9). ${ }^{[12]}$ 

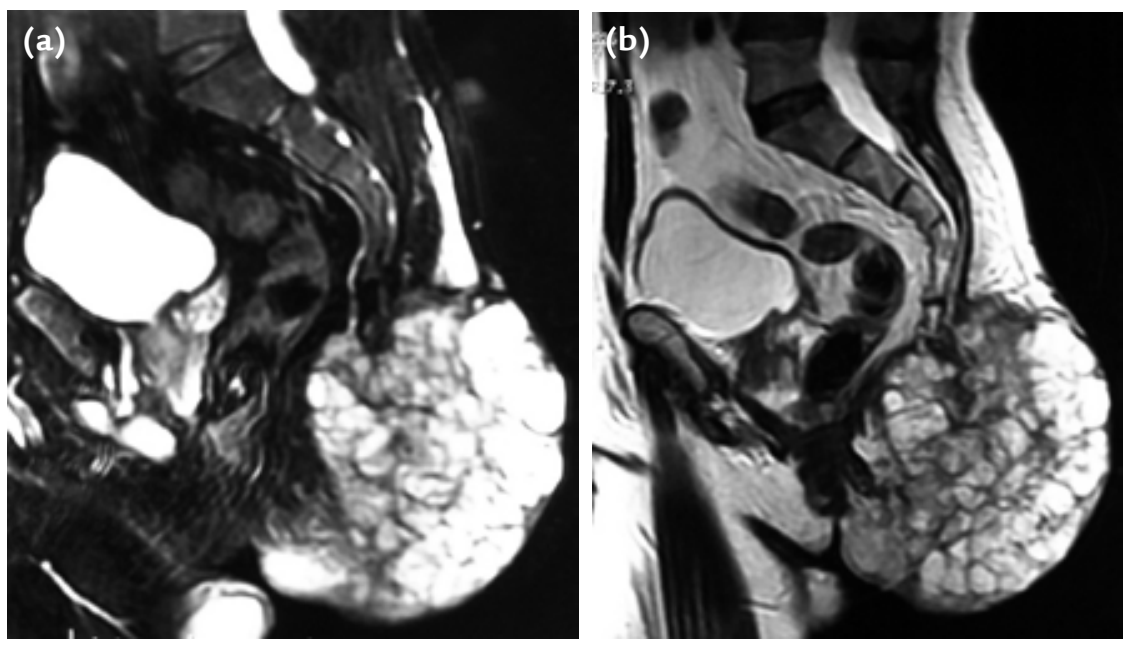

Şekil 9. Oldukça uzun süre ihmal edilmiş ve büyük boyutlara ulaşmış sakrokoksigeal kordoma olgusunda, total en-blok rezeksiyona ek olarak, inguinal lenfatik metastazların rezeksiyonu. Hastada, rektumu da açıkta bırakan rezeksiyon sonrası defekt, bilateral gluteal ilerletme flepleri ile giderilmiştir.

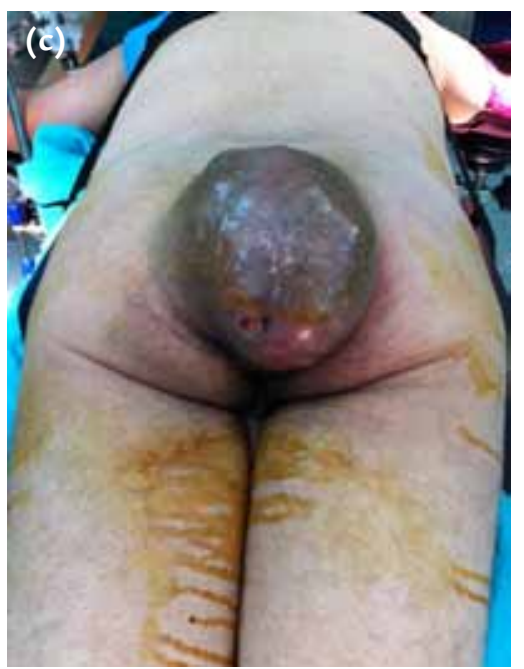

(d)
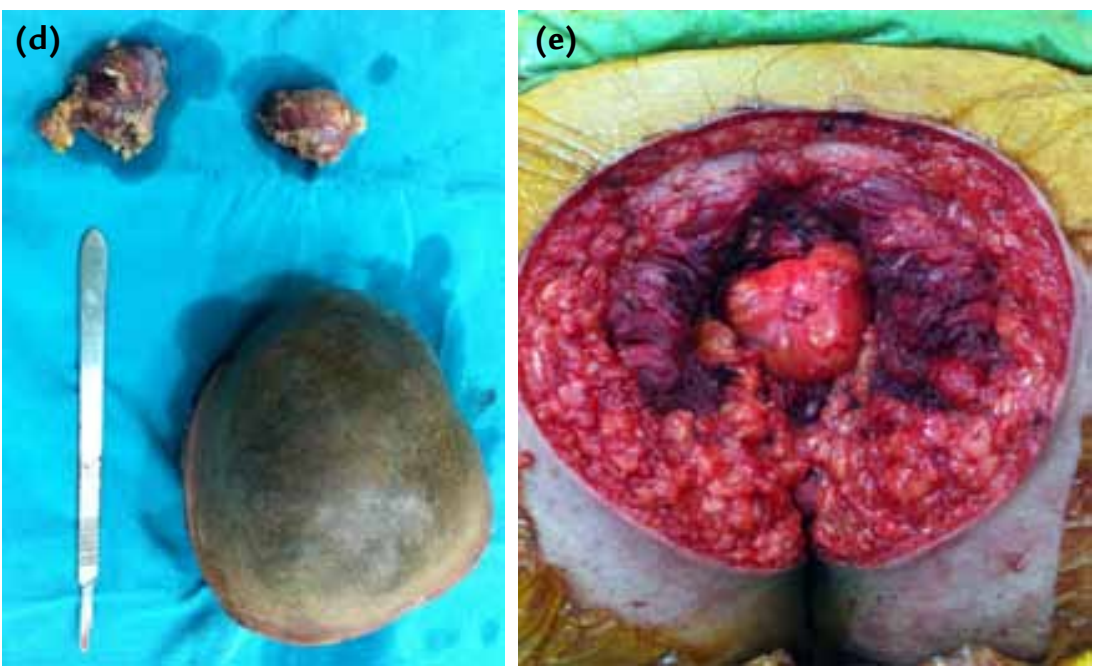

(g)

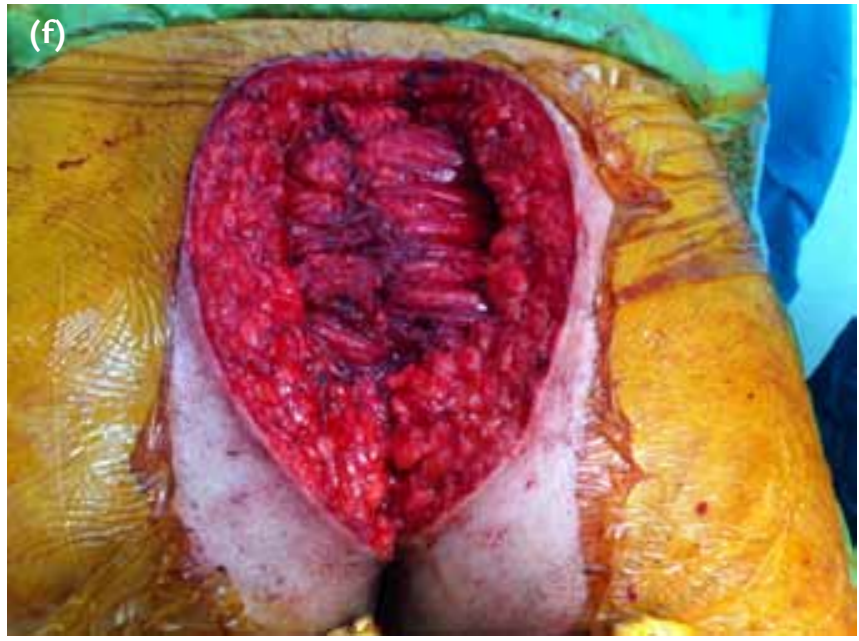

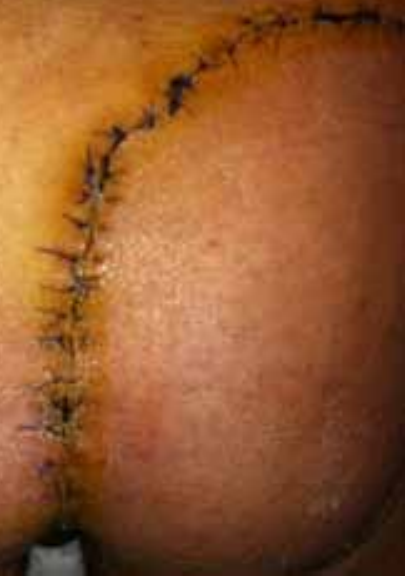

Eksternal radyoterapi, bu tümörde palyatif amaçla kullanılabilir. Tümör genellikle radyorezistandır. Radyoterapi rezeksiyonu mümkün olmayan olgular ya da nüks olgularda uygulama alanı bulmaktadır. Ancak, radyoterapi kararından önce, lokal yumuşak doku sorunlarının da eklenmesiyle cerrahi çok güçleşeceğinden, hastanın bu konuda deneyimli bir merkeze gönderilmesi veya görüş alınması uygun olacaktır. 
Benzer şekilde, kordomalar konvansiyonel kemoterapiye de dirençli tümörlerdir. Ancak, son yıllarda tirozin kinaz ve anjiyogenez üzerine etkili moleküler hedef ajanlarla (imatinib, tarceva ve irissa gibi) alınan başarılı sonuçlar bildirilmektedir. ${ }^{[21]}$

\section{Lenfoproliferatif Tümörler}

\section{Multipl Miyelom ve Soliter Plazmositom}

Multipl miyelom, plazma hücrelerinden köken alan ve çok sayıda osteolitik kemik lezyonu ya da diffüz osteoporoz nedeni olan bir tümördür. Non-Hodgkin lenfomadan sonra en sık ikinci hematolojik malignitedir. Hastalık, tipik olarak kemik iliğinde malign plazma hücre infiltarsyonu, serum ve/veya idrarda monoklonal immünglobülinlerin sekresyonu ile karakterizedir.

Olguların \%5'inde tümör, soliter plazmositom (SP) olarak ortaya çıkar. Hastaların üçte ikisinde soliter lezyon sonunda MM'ye dönüşse de, bazı hastalarda, tümör yalnızca lokalize seyreder. MR, soliter olarak görülen birçok hastada, kemik iliğinde birçok alanda sinyal değişikliklerini göstererek MM'yi teyit edebilir. Prognoz, SS'de MM'ye göre belirgin olarak iyidir (ortalama sağkalım sırasıyla 60 ay ve 28 ay). ${ }^{[12]}$

MM hastalarında, sistemik bulgulara ek olarak (iştahsızık, ateş, halsizlik, kilo kaybı), yaygın kemik ağrıSı ön plandadır. MM ve SP'de, patolojik kırık veya direkt kitle etkisine bağlı spinal kord kompresyonu sık görülmektedir. Bu nedenle, patolojik kırıkla başvuran, ancak primer patolojisi bilinmeyen hastalarda, serum protein ve immün elektroforezi yapılmalıdır.

MM'de, böbrek yetmezliği ve hiperkalsemi, sık görülen bulgulardır. Özellikle kontrastlı görüntülemelere başvurmadan önce, hastalar böbrek fonksiyonlarını da içeren kan biyokimyası ile değerlendirilmelidir.

Patolojik kırıklar ya da nörolojik semptomlarla komplike olan olgularda, perkütan sement enjeksiyonları \%80'e yakın ağrı palyasyonu sağlar. Bu uygulamada, özellikle komşu segment kırığı riski yüksek olduğundan, çoklu vertebroplasti/kifoplasti akılcı bir seçenek olacaktır. Tek seferde yüksek miktarda uygulanan semente bağlı emboli riskini azaltmak için, çoklu sement enjeksiyonu yapılacak olgular, birden çok seansta tedavi edilebilir. ${ }^{[22]}$

MM'de tedavi temelde kemoterapidir. Klasik tedaviye ek olarak, son yıllarda tedavi seçeneklerinde ciddi değişimler olmuştur. Thalidomide-dekzametazon kombinasyonuna ek olarak, proteozom inhibitörleri, kişiye özel tedavide önemli avantajlar sağlamaktadır. Yaygın osteporoz ve litik kemik lezyonlarına bağlı ağrı için, bifosfonatlar (zoledronik ve pamidronik asit gibi) oldukça etkilidir.

\section{METASTATIK OMURGA LEZYONLARI}

Metastatik omurga lezyonlarında, bazı soliter lezyonlar dışında, tedavi semptomatiktir ve temel amaç, ağrıyı gidermek, paralizi riskini önlemek ve günlük yaşam kalitesini arttırmaktır. Birçok hastada, eşlik eden sistemik sorunlar mevcuttur ve bu nedenle tedavi seçimi ciddi önem arzetmektedir.

Omurga metastazları, birkaç farklı tabloyla karşımıza çıkabilir. Bunlardan ilki, kanser öyküsü bulunan hasta grubudur. Bu hastalarda, primer odağın bilinmesi, büyük olasıkla omurga lezyonunun metastatik olduğunu düşündürse de, bazı atipik olgularda histolojik konfirmasyon gerekebilir (Şekil 10).

Eğer primer lezyon bilinmiyorsa, ağrı ve paralizinin önlenmesi amacıyla, planlama yapılırken, primer odağa yönelik araştırma da başlatılmalıdır. Bilindiği gibi, kemik metastazları, sıklıkla erkeklerde, sırasıyla akciğer, prostat, böbrek, karaciğer ve gastrointestinal sistem, kadınlarda ise meme, akciğer, uterus, tiroid ve meme kanseri, kökenlidir. Buna bağlı olarak, hastalarda toraks ve tüm batın tomografisi ve serum analizleri (protein ve immun elektroforez ve karsinom belirteçleri) uygulanmalıdır. Yine, neoplastik sürecin yaygınlığının araştırılması amacıyla, PET-CT iyi bir seçenektir. Bu araştırmalara rağmen primer odağın bulunmaması durumunda, biyopsi yapılmalıdır. Bu hastalarda, genellikle perkütan biyopsi tanı koydurucudur, ancak immünohistokimyasal çalışmalara gerek duyulacağından, yeterli miktarda örnek alındığından emin olunmalıdır.

Metastatik lezyonlarda tedavi seçenekleri; başlıca, medikal (hormon tedavileri, kemoterapi, bifosfonatlar ve radyoterapi) ve cerrahi (perkütan vertebroplasti ve kifoplasti, perkütan radyofrekans ablasyon, minimal invaziv cerrahi ve açık konvansiyonel cerrahi) olarak ayrılmaktadır. Tedavi seçenekleri ve tedavi kararı, medikal onkolog ve radyasyon onkoloğu ile birlikte değerlendirilmeli ve karar verilmelidir.

Genel olarak cerrahi endikasyonlar, spinal instabilite veya kord basısına yol açan ağrı ve paralizi, radyoterapiye rağmen büyüme gösteren karsinomlar, konservatif tedaviye rağmen ağrı palyasyonu sağlanamamasıdır ve soliter lezyonlarda en-blok rezeksiyonun sağkalıma katkıda bulunacağı hastalardır.

Ancak, cerrahi öncesi hastanın sistemik açıdan ayrıntılı olarak değerlendirilmesi gerekir. Cerrahi, birçok hasta için uygun bir seçenek olmayabilir. Hastaların uzun sürecek ve genel anestezi gerektirecek girişimleri tolere edebilecek kondüsyonda olmaları ve bu tedaviyi istemeleri temel kuraldır. Diğer bir kriter, olası yaşam beklentisidir. Burada temel belirleyici, primer kanserin doğal seyri olacaktır. Genel olarak, hastanın yaşam 


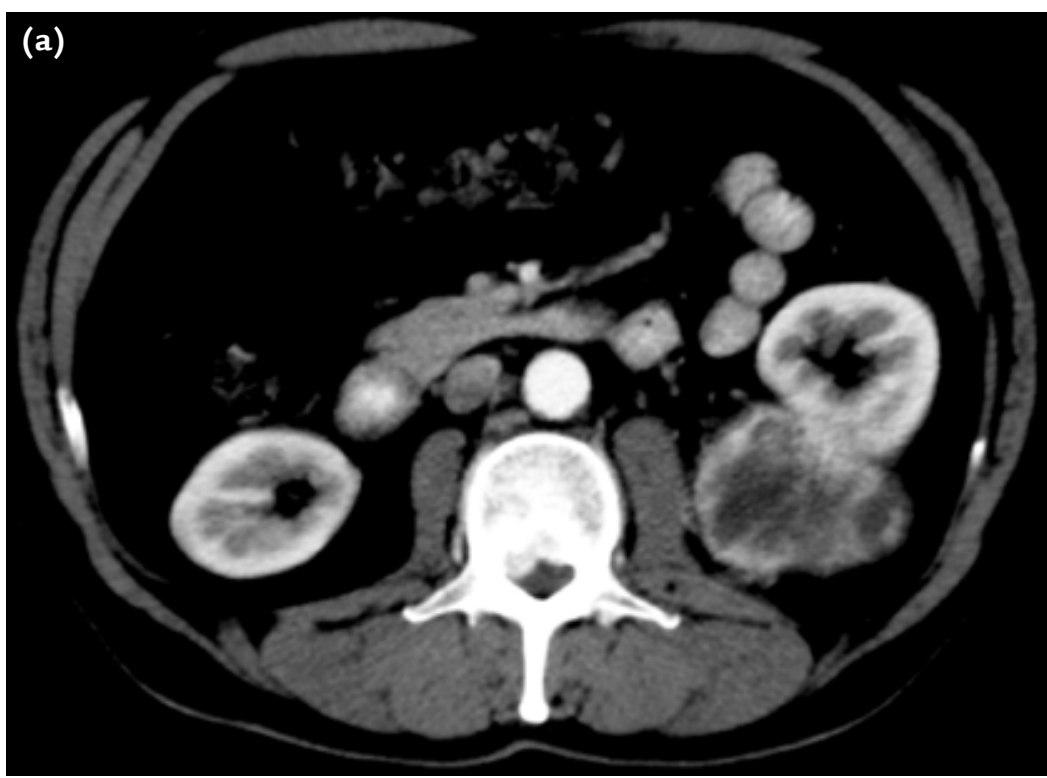

Şekil 10. Bir hipernefroma hastasında, böbrekteki kitleye ek olarak, omurga orta kolonunda yerleşim gösteren ve kord basısına yol açan çoklu metastatik odaklar.

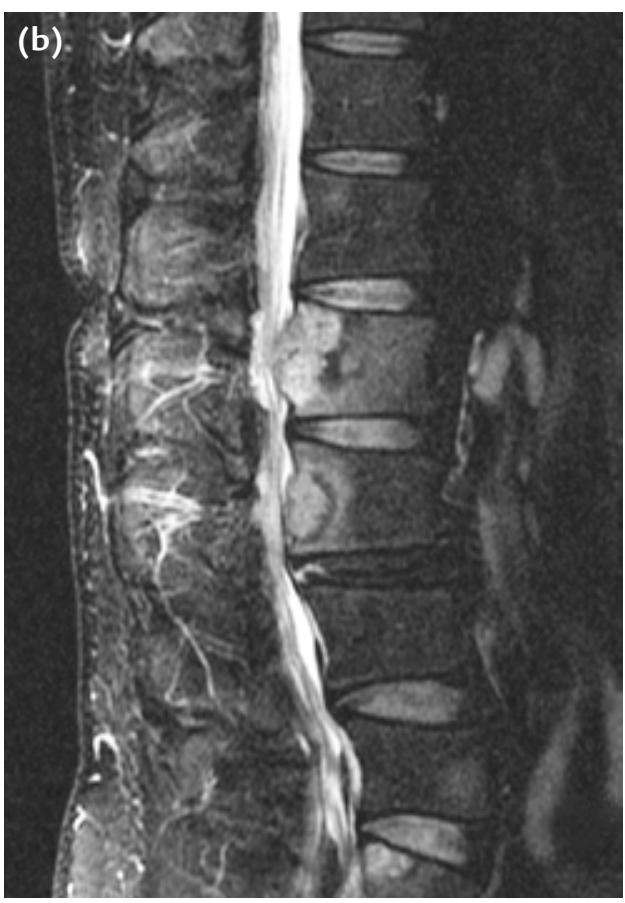

beklentisi 3-6 ay veya daha uzun ise, cerrahi tedavi önerilebilir (Şekil 11).

Cerrahi tedavi öncesi birçok skorlama sistemi geliştirilmiştir. Bunların arasında, Tokuashi ve arkadaşları tarafından geliştirilen sistem sıklıkla kullanılmaktadır. Burada temel olarak, hastanın genel durumu, omurga dışı kemik metastazlarının sayısı, omurga içindeki metastazlar, majör visseral metastazlar, primer odak, ve nörolojik durum değerlendirilmekte ve böylece hangi hastaların cerrahi için uygun olduğu belirlenmektedir. ${ }^{[23]}$

\section{Metastatik Omurga Lezyonlarında Cerrahi Girişimler}

\section{Perkütan Vertebroplasti ve Kifoplasti}

Perkütan vertebroplasti ve kifoplasti (VP/KP), ağrı palyasyonuna yönelik bir girişimdir ve omurga metastazı bulunan, ancak yaşam beklentisi sınırlı olgularda açık cerrahi tolere edilemeyecekse, nörolojik defisit ya da belirgin vertabral instabiliteye yol açmayan lezyonlarda endikedir. Bu hastalarda, perkütan VP/KP, hızlı bir stabilizasyon ve ağrı palyasonu sağlayan ve dolayısı ile hastanın yaşam kalitesini arttıran bir girişimdir. Ancak, ciddi vertebra kollapsı riski taşıyan olgular dışında, asemptomatik hastalarda ya da medikal tedavi veya radyoterapiyle ağrı palyasyonu sağlanabilecek olgularda endike değildir. Benzer şekilde, vertebrada enfeksiyon varlığı ya da hastada ciddi hemoraji eğilimi varsa uygulanmamalıdır. Spinal kord kompresyonuna bağlı progresif nörolojik defisit, ileri derecede vertebral kollaps ve omurga cismi arkasında kortikal destrüksiyon (intramedüller semen kaçağı riski) rölatif kontrendikasyon teşkil eder. ${ }^{[22]}$

Yapılan çalışmalar, perkütan VP/KP ile hastaların yaklaşık \%80-90'ında etkili ağrı palyasyonu sağlandığını göstermektedir. Ağrı palyasyonunun, kısmen tümör dokusunun vertebra cisminde yarattığı mikro-kırıkların sement enjeksiyonu ile stabil hale gelmesi, kısmen de ağrıyı ileten sinir uçlarının termal ablasyonundan kaynaklandığı düşünülmektedir. ${ }^{[24,25]}$

Perkütan VP/KP'nin komplikasyon oranları, metastatik hastalarda osteporotik kırıklara göre daha yüksektir. Buna yol açan en önemli neden, kortikal destrüksiyonun metastazlarda daha sık görülmesidir. Kortikal defektlere bağlı olarak, değişik lokalizasyonlarda sement kaçağı görülebilmektedir. Ancak, birçok hastada sement kaçağı asemptomatiktir. Sement kaçağı, sıklık sırasıyla, paravertebral venöz pleksus ve yumuşak dokular, komşu disk, spinal kanal veya nöral foramende görülür. Olguların yarısından fazlasında, radyolojik olarak dokümante edilebilen sement kaçağı görülmesine rağmen, cerrahi dekompresyon endikasyonu yaklaşık \%5 civarındadır. ${ }^{[26]}$

Özellikle multipl miyelomda ve yaygın omurga metastazları varlığında, perkütan VP/KP sonrası komşu segment kırığı görülebilmektedir (\%20-25). Bu oran, sement enjekte edilen omurga gücünde ciddi artışla ilişkilidir ve kifoplastide vertebroplastiye göre daha fazladır. ${ }^{[27]}$ 

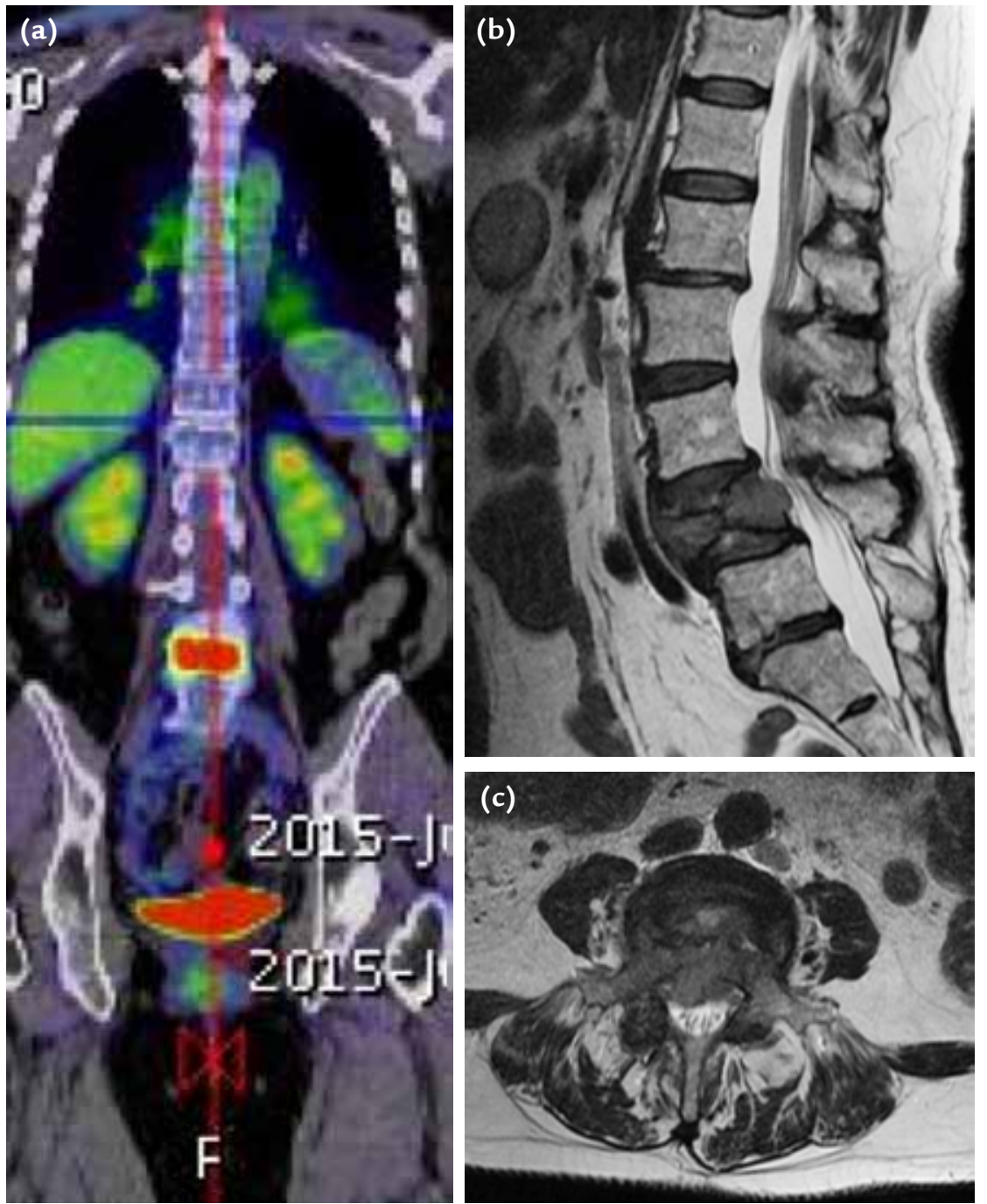

Şekil 11. Akciğer kanseri, en sık kemik metastazı yapan tümörlerden biridir. Bu olguda, L4 omurgada patolojik kırığa ve kanal basısına yol açan ve vertebrada instabilite oluşturan metastatik lezyon izlenmektedir. Hastadaki klinik tablo nedeniyle, perkütan girişimler kontrendike olup, korpektomi ve stabilizasyon tercih edilmiştir.

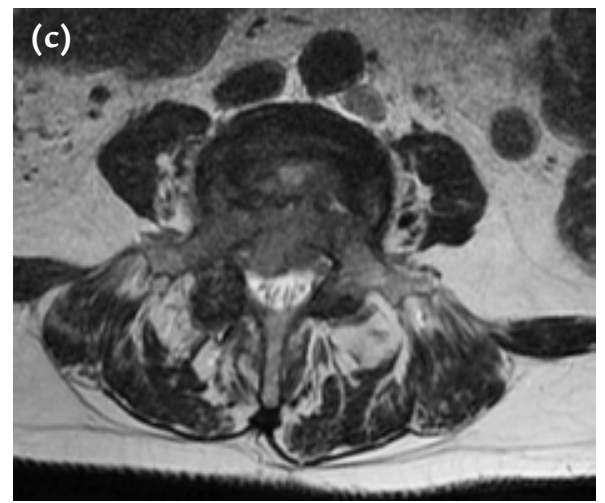

\section{Perkütan Radyofrekans Ablasyon (RFA)}

Görüntüleme eşliğinde uygulanan RFA, oluşturduğu ısı nekrozu ile tümör hastalarında etkili bir ağrı palyasyonu sağlar. Özellikle metastaz hastalarında RFA, lokal ve sedasyonla, hastaya ciddi bir anestezi yükü getirmeden uygulanabilmektedir. RFA, gerek sinir uçlarının ablasyonu gerekse tümör nekrozuna bağlı tümör hacmini azalması ve tümör hücreleri tarafından salgılanan ağrı mediyatörlerinin ortadan kalkması ve son olarak da osteoklastik aktivitenin inhibisyonuyla etkili olmaktadır. Ancak, spinal korda çok yakın $(<1 \mathrm{~cm})$ lezyonlarda uygulanmamalıdır.

Spinal instabilitesi olan hastalarda, perkütan RFA uygulamasından sonra sement enjeksiyonu kombinasyonu ile başarılı sonuçlar alınmaktadır. Perkütan RFA, omurga cismindeki tümör hacmini azalttığından, sement kaçă̆ı olasıı ı̆ını da azaltmaktadır. ${ }^{[28]}$

\section{Minimal Invaziv Omurga Cerrahisi (MiC)}

Spinal metastazların cerrahi tedavisi, önceleri laminektomiyle yapılmaktaydı. Ancak, bu yöntem birçok hastada ilerleyici instabilite yaratmış ve sonraları total dekompresyon ve stabilizasyon gündeme gelmiştir. Ancak, bu agresif cerrahi, ilerlemiş neoplastik hastalığa bağlı bağışıklık sistemi düşük ve genel durumu bozuk birçok hastada ciddi morbidite ve komplikasyonlara yol açabilmektedir. Bu hastalarda MiC, yumuşak doku hasarını ve cerrahi morbiditeyi azaltarak hızlı bir iyileşme sağlayabilir. Temel olarak, endoskopik girişimler ve minimal yaklaşım cerrahileri tanımlanmıştır. Özellikle, yaşam beklentisi üç ayın altında olan ya da genel durumu uzun sürecek açık dekompresyon ve stabilizasyonu tolere edemeyecek hastalarda, bir ya da iki seviyeli tümör kompresyonuna bağlı nörolojik bulgular veya vertebra kollapsı sözkonusu olduğunda, MiC endikedir. ${ }^{[22]}$ 
MiC sırasında tüm girişim intralezyonel bir rezeksiyon olduğundan, özellikle soliter renal hücreli karsinom gibi en-blok rezeksiyon gerektiren olgularda, konvansiyonel açık cerrahi tercih edilmelidir. Ancak, bu hastalarda en-blok rezeksiyona karar vermeden önce, iskelet ve visseral sistem taranarak, hastada izole metastaz olduğu teyit edilmelidir. Renal hücreli karsinom dişında, nispeten yavaş gidişli ve kemoterapi ve radyoterapiyle uzun yaşam beklentisi olan hastalarda (meme, prostat ca gibi), primer malign tümörde olduğu gibi, sporadik olarak, en-blok rezeksiyonlar uygulanmaktadır. Ancak, bu agresif cerrahinin, kanıta dayalı tıp açısından etkinliği henüz gösterilmiş değildir. ${ }^{[29]}$

Özetle; primer ve metastatik omurga tümörleri, ortopedik onkolojinin tedavide güçlük arzeden ve ciddi deneyim gerektiren olgularındandır. Birçok hastada, zamanında ve doğru tanı ve tedavi yöntemleriyle başarılı sonuçlar alınırken, plansız cerrahilerin ve doğru yönetilmeyen tedavilerin, ciddi morbidite veya mortaliteyle sonuçlanacağı bilinmelidir. Bu nedenle, bu hasta grubunda, tanı ve tedavi basamaklarından önce, en azından konu ile ilgili deneyimli cerrah ve merkezlerden görüş alınmalı veya hasta tercihan ilgili merkeze yönlendirilmelidir.

\section{KAYNAKLAR}

1. Clarke MJ, Mendel E, Vrionis FD. Primary spine tumors: diagnosis and treatment. Cancer Control 2014;21(2):114-23.

2. Downie A, Williams CM, Henschke N, Hancock MJ, Ostelo RW, de Vet HC, Macaskill P, Irwig L, van Tulder MW, Koes BW, Maher CG. Red flags to screen for malignancy and fracture in patients with low back pain: systematic review. BMJ 2013;347:f7095. CrossRef

3. Airaksinen O, Brox JI, Cedraschi C, Hildebrandt J, KlaberMoffett J, Kovacs F, Mannion AF, Reis S, Staal JB, Ursin $\mathrm{H}$, Zanoli G; COST B13 Working Group on Guidelines for Chronic Low Back Pain. Chapter 4. European guidelines for the management of chronic nonspecific low back pain. Eur Spine J 2006;15 Suppl 2:S192-300.

4. Ofluoglu O, Boriani S, Gasbarrini A, De lure F, Donthineni R. Diagnosis and planning in the management of musculoskeletal tumors: surgical perspective. Semin Intervent Radiol 2010;27(2):185-90. CrossRef

5. Donthineni R. Diagnosis and staging of spine tumors. Orthop Clin North Am 2009;40(1):1-7. CrossRef

6. Enneking WF, Spanier SS, Goodman MA. A system for the surgical staging of musculoskeletal sarcoma. Clin Orthop Relat Res 1980;(153):106-20.

7. Boriani S, Weinstein JN, Biagini R. Primary bone tumors of the spine. Terminology and surgical staging. Spine (Phila Pa 1976) 1997;22(9):1036-44.

8. Tomita K, Kawahara N, Baba H, Tsuchiya H, Fujita T, Toribatake Y. Total en bloc spondylectomy. A new surgical technique for primary malignant vertebral tumors. Spine 1997;22(3):324-33.
9. Ransford AO, Pozo JL, Hutton PA, Kirwan EO. The behaviour pattern of the scoliosis associated with osteoid osteoma or osteoblastoma of the spine. J Bone Joint Surg Br 1984;66(1):16-20.

10. Schwab J, Gasbarrini A, Bandiera S, Boriani L, Amendola L, Picci P, Ferrari S, Boriani S. Osteosarcoma of the mobile spine. Spine (Phila Pa 1976) 2012;37(6):E381-6. CrossRef

11. Ozaki T, Flege S, Liljenqvist U, Hillmann A, Delling G, SalzerKuntschik M, Jürgens $H$, Kotz R, Winkelmann W, Bielack SS. Osteosarcoma of the spine: experience of the Cooperative Osteosarcoma Study Group. Cancer 2002;94(4):1069-77.

12. Sundaresan N, Rosen $G$, Boriani S. Primary malignant tumors of the spine. Orthop Clin North Am 2009;40(1):21-36. CrossRef

13. Boriani S, De lure F, Bandiera S, Campanacci L, Biagini R, Di Fiore M, Bandello L, Picci P, Bacchini P. Chondrosarcoma of the mobile spine: report on 22 cases. Spine (Phila Pa 1976) 2000;25(7):804-12.

14. Gasbarrini A, Cappuccio M, Donthineni R, Bandiera S, Boriani S. Management of benign tumors of the mobile spine. Orthop Clin North Am 2009;40(1):9-19. CrossRef

15. Boriani S, Lo SF, Puvanesarajah V, Fisher CG, Varga PP, Rhines LD, Germscheid NM, Luzzati A, Chou D, Reynolds JJ, Williams RP, Zadnik P, Groves M, Sciubba DM, Bettegowda C, Gokaslan ZL; AOSpine Knowledge Forum Tumor. Aneurysmal bone cysts of the spine: treatment options and considerations. J Neurooncol 2014;120(1):171-8. CrossRef

16. Ma $Y, X u$ W, Yin $H$, Huang $Q$, Liu $T$, Yang $X$, Wei $H$, Xiao J. Therapeutic radiotherapy for giant cell tumor of the spine: a systemic review. Eur Spine J 2015;24(8):1754-60. CrossRef

17. Goldschlager T, Dea N, Boyd M, Reynolds J, Patel S, Rhines LD, Mendel E, Pacheco M, Ramos E, Mattei TA, Fisher CG. Giant cell tumors of the spine: has denosumab changed the treatment paradigm? J Neurosurg Spine 2015;22(5):526-33. CrossRef

18. Mattei TA, Ramos E, Rehman AA, Shaw A, Patel SR, Mendel E. Sustained long-term complete regression of a giant cell tumor of the spine after treatment with denosumab. Spine J 2014;14(7):e15-21. CrossRef

19. Donthineni R, Boriani L, Ofluoglu O, Bandiera S. Metastatic behaviour of giant cell tumour of the spine. Int Orthop 2009;33(2):497-501. CrossRef

20. Marco RA, Gentry JB, Rhines LD, Lewis VO, Wolinski JP, Jaffe $\mathrm{N}$, Gokaslan ZL. Ewing's sarcoma of the mobile spine. Spine (Phila Pa 1976) 2005;30(7):769-73.

21. Bydon M, Papadimitriou K, Witham T, Wolinsky JP, Bydon A, Sciubba D, Gokaslan Z. Novel therapeutic targets in chordoma. Expert Opin Ther Targets 2012;16(11):1139-43. CrossRef

22. Ofluoglu O. Minimally invasive management of spinal metastases. Orthop Clin North Am 2009;40(1):155-68. CrossRef

23. Tokuhashi $Y$, Ajiro Y, Oshima M. Algorithms and planning in metastatic spine tumors. Orthop Clin North Am 2009;40(1):37-46. CrossRef

24. Alvarez L, Pérez-Higueras A, Quiñones D, Calvo E, Rossi RE. Vertebroplasty in the treatment of vertebral tumors: postprocedural outcome and quality of life. Eur Spine J 2003;12(4):356-60.

25. Celmels V, Valée JN, Rose M, Chiras J. Osteobalstic and mixed spinal metastases; evaluation of analgesic efficiency of percutaneous vertebroplasty. AJNR Am J Neuroradiol 2007;28(3);570-4. 
26. Cotten A, Dewatre F, Cortet B, Assaker R, Leblond D, Duquesnoy B, Chastanet P, Clarisse J. Percutaneous vertebroplasty for osteolytic metastases and myeloma: effects of the percentage of lesion filling and the leakage of methyl methacrylate at clinical follow-up. Radiology 1996;200(2);525-30.

27. Lieberman I, Reinhardt MK. Vertebroplasty and kyphoplasty for osteolytic vertebral collapse. Clin Orthop Relat Res 2003; (415 Suppl):S176-86.
28. Schaefer $O$, Lohmann $C$, Markmiller $M$, Uhrmeister $P$, Langer M. Technical innovation. Combined treatment of a spinal metastasis with radiofrequency heat ablation and vertebroplasty. AJR Am J Roentgenol 2003;180(4);1075-7.

29. Sciubba DM, Nguyen T, Gokaslan ZL. Solitary vertebral metastasis. Orthop Clin North Am 2009;40(1):145-54. CrossRef 